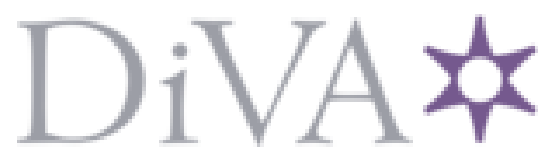

http://www.diva-portal.org

\title{
Postprint
}

This is the accepted version of a paper published in Ocean Development and International Law. This paper has been peer-reviewed but does not include the final publisher proof-corrections or journal pagination.

Citation for the original published paper (version of record):

Song, Y-h., Tønnesson, S. (2013)

The Impact of the Law of the Sea Convention on Conflict and Conflict Management in the South China Sea.

Ocean Development and International Law, 44(3): 235-269

http://dx.doi.org/10.1080/00908320.2013.808935

Access to the published version may require subscription.

N.B. When citing this work, cite the original published paper.

Permanent link to this version:

http://urn.kb.se/resolve?urn=urn:nbn:se:uu:diva-214300 


\section{The Impact of the Law of the Sea Convention on Conflict and Conflict Management in the South China Sea}

Yann-Huei Song

Institute of European and American Studies

Academia Sinica, Taipei

Taiwan, R.O.C., and East Asian Peace Program,

Department of Peace and Conflict Research, Uppsala University, Sweden

Stein Tønnesson

East Asian Peace Program

Department of Peace and Conflict Research, Uppsala University, Sweden, and Peace Research Institute Oslo (PRIO), Norway

Received: 2 October 2012; accepted: 14 January 2013.

Address correspondence to: Dr. Yann-huei Song, Institute of European and American Studies, Academia Sinica, Nangang (115), Taipei, Taiwan, R.O.C. E-mail: yhsong@sinica.edu.tw . Dr. Stein Tønnesson, Peace Research Institute Oslo (PRIO), PO Box 9229 Grønland, NO-0134 Oslo, Norway. E-mail: stein@prio.no .

The article builds on a paper presented at the workshop Securing Maritime Peace in East Asia: The Role of International Law, held at the University of Central Lancashire, Preston, U.K. on 23-24 April 2012. The authors would like to thank all workshop participants for helpful suggestions and comments. 


\section{Abstract}

This article examines the impact of the UN Law of the Sea Convention on conflict behavior and management in the South China Sea during four periods: its negotiation (1973-1982); from its signing to the entry into force (1982-1994); from then until the China-ASEAN Declaration on the Conduct of Parties in the South China Sea (1995-2002); and from the setting of a timeline for outer limit of continental shelf submissions to the events following the 2009 submissions (2003-2013). The authors find ambiguous effects. The Convention has on the one hand, generated or exacerbated conflict by raising the stakes, failing to resolve key legal issues, and encouraging overlapping zone claims. On the other hand, it has provided obligations, language and techniques for conflict management and resolution. The article finds the conflict enhancing impact to have been more substantial than the peace promoting effects. Nevertheless, the balance has shifted towards more emphasis on conflict management and also some utilization of the Convention's peace-making potential. If this long term trend continues and the Convention is more rigorously respected and applied, the Convention may in the end be found to have contributed to regional peace.

Keywords: South China Sea, dispute resolution, LOS Convention 


\section{Introduction}

The year 2012 marked the $30^{\text {th }}$ anniversary of the United Nations Convention on the Law of the Sea (LOS Convention), ${ }^{1}$ which was adopted by the Third United Nations Conference on the Law of the Sea (UNCLOS III) and opened for signature, together with the Final Act of the Conference, at Montego Bay, Jamaica, on 10 December 1982. The Convention, considered "[a] Constitution for the Oceans," ${ }^{2}$ consists of 17 parts, 9 annexes, and 320 articles. Designed to regulate the use and utilization of 70 percent of the Earth's surface, the Convention has been praised as the most comprehensive political and legislative work ever undertaken by the United Nations. Numerous new concepts related to the use of the oceans were developed, such as: transit passage; archipelagic waters; exclusive economic zones (EEZs); and the International Seabed Authority. The Convention entered into force on 16 November 1994, and as of 30 January 2013, 165 States and entities were party to it.

All of the countries bordering the South China Sea are parties to the LOS Convention, with the exception of Cambodia and the Republic of China (Taiwan). Although Taiwan is not a party, its government has agreed to be bound by the Treaty on a voluntary and reciprocal basis. ${ }^{3}$

It is stated in the preamble of the LOS Convention that the codification and progressive development of the law of the sea "will contribute to the strengthening of peace, security, co-operation and friendly relations among all nations in conformity with the principles of justice and equal rights." The question to be discussed in this article is if this did happen in the South China Sea during the period when the Convention was negotiated (1973-1982) and in the thirty years after it was adopted (1983-2013). Has the Convention strengthened peace, security, co-operation and friendly relations among the South China Sea countries? Or has it instead disrupted the peace and undermined cooperation by raising the stakes of sovereignty disputes? This is part of a larger question concerning the impact of law on international relations: does 
international law promote peace and cooperation or create new battlegrounds? If both, then which effect is predominant?

The question in the context of the South China Sea is if the LOS Convention has mainly exacerbated sovereignty and maritime disputes by encouraging conflicting claims or has constrained aggressive behavior and helped manage or resolve disputes among the countries involved. ${ }^{4}$ It is immediately clear that one of the main sources of rising tension and escalation of conflict in the South China Sea has been the EEZ and continental shelf claims made by States on the basis of the provisions in the Convention. States have enacted domestic maritime legislation in accordance with the provisions and established maritime zones that overlap with zones claimed by other States, and this has given rise to conflicts, which have threatened peace and stability. On the other hand, the parties to the disputes, as well as other countries concerned, have repeatedly urged that the conflicts be dealt with by peaceful means in accordance with international law. The Convention has rules and procedures that have been used to successfully delimitate maritime zones through negotiation in many parts of the world, including the margins of the South China Sea, and such rules have been further developed by precedents set in third party adjudications and negotiated treaties concerning various parts of the world's coastal waters. The Convention and these precedents could serve a peace-promoting function in hotly disputed areas such as the South China Sea. It could also be argued that the main sources of tension have not been the national legislation and other actions that comply with the provisions of the Convention, but the tendency of States to make extravagant claims with no or scant basis in the Treaty.

The above are the questions to be discussed in this article, which will mainly deal with Parts V, VI, VIII and IX of the Convention about, respectively, the EEZ, the continental shelf, the regime of islands, and semi-enclosed seas. Although the question of whether or not there is 
an area (a "doughnut") in the middle of the South China Sea beyond the national jurisdiction of States over the continental shelf, as measured from any side, is important, this question has not so far had much impact on tension or cooperation among the interested countries. This article also does not discuss the issue of navigational rights, although this is highly relevant to how international law affects conflict behavior. The main reason for omitting this question is that the conflict over navigational rights within the territorial sea and EEZ is primarily between China and countries outside the region, such as Australia, India, Japan and in particular the United States, not between the local States. Moreover the LOS Convention's provisions concerning the freedom of navigation were not new having been agreed upon earlier in the 1958 Geneva Conventions. $^{5}$

At the level of official rhetoric, peace and law walk hand in hand. Since 1995 all the member States of the Association of Southeast Asian Nations (ASEAN) have publicly and repeatedly agreed to seek a peaceful resolution of the South China Sea disputes and they have explored ways and means to prevent conflict and enhance cooperation consistent with the provisions of the relevant treaties, declarations, and international law, including the LOS Convention. ${ }^{6}$ China joined the member States of ASEAN at the $3^{\text {rd }}$ meeting of the ASEAN Regional Forum (ARF), held in Jakarta in July 1996, and agreed to seek solutions to disputes by peaceful means in accordance with international law in general and the LOS Convention in particular. ${ }^{7}$ The political commitment made by the ASEAN member countries and China 15 years ago remains valid today. At the $6^{\text {th }}$ East Asia Summit in Bali, in November 2011 the 18 national leaders or their representatives recognized that "the international law of the sea contains crucial norms that contribute to the maintenance of peace and stability in the region" and reaffirmed their determination "to promote a democratic and just world order based on the supremacy of principles and norms of international law, and on the need to use relevant 
multilateral instruments, finding solutions to regional and global problems through concerted efforts." ${ }^{\prime 8}$ At the $20^{\text {th }}$ ASEAN Summit in April 2012, the ten leaders of the ASEAN member countries agreed to uphold "the universally recognized principles of international law, including the 1982 United Nations Convention on the Law of the Sea (UNCLOS), and to move for the eventual realization of a regional code of conduct (COC)." ${ }^{\prime 9}$ They also reaffirmed the importance of the 2002 China-ASEAN Declaration on the Conduct of Parties in the South China $\mathrm{Sea}^{10}$ as a milestone document that embodies the collective commitment to promoting peace, stability, and mutual trust in the South China Sea and to ensuring the peaceful resolution of disputes in this area in accordance with the UN Charter and the universally recognized principles of international law, including the LOS Convention. ${ }^{11}$ In July 2012, the foreign ministers and representatives of the $19^{\text {th }}$ ASEAN Regional Forum "called upon all parties to undertake peaceful resolution of the disputes in the area in accordance with the recognized principles of international law, including the 1982 UNCLOS." And at the $22^{\text {nd }}$ ASEAN Summit in Bandar Seri Begawan, Brunei, 24-25 April 2013, the ASEAN Member States reaffirmed their collective commitment to "ensuring the peaceful resolution of disputes in accordance with universally recognised principles of international law, including the 1982 United Nations Convention on the Law of the Sea, without resorting to the threat or use of force, while exercising self-restraint in the conduct of activities." ${ }^{12}$ It is clear that the LOS Convention is generally considered to play a crucial role in helping manage, if not resolve, maritime disputes.

This article examines the impact of the LOS Convention on conflict and conflict management in the South China Sea in four periods since 1973. The key questions to be asked for each period are:

- Did the LOS Convention exacerbate maritime disputes by encouraging conflicting claims? and/or: 
- Did the LOS Convention help manage or resolve conflicts?

The article is organized in six parts. Part two examines the sovereignty and maritime claims made by the countries that border the South China Sea before the adoption of the LOS Convention, together with a discussion of their positions taken during the UNCLOS III (19731982) on some of its key articles. Parts three, four and five discuss the impact of the Convention on conflict and conflict management in the South China Sea during 1982-1994, 1995-2002, and 2003-2013 respectively. Part six provides an overall assessment of the role played by the LOS Convention in conflict and conflict management in the South China Sea over the last three decades and suggests some possible ways forward to enhance the peace promoting role of the Convention.

\section{Actions Taken by the Claimant States during UNCLOS III, 1973-1982}

In the early 1970s, the possibility of finding vast hydrocarbon resources in offshore areas of the Yellow Sea, East China Sea and South China Sea first arose. Although the Paracel and Spratly Islands had been disputed by the shifting littoral States for a century or more ${ }^{13}$ the interest and attention from governments to these sovereignty disputes now took on a new dimension. It seemed likely that possession of these islands could be a key to claiming rights to resources in the area around them. While the prospect of finding hydrocarbons became an interest for oil companies as well as governments, legal developments were also happening on the global level potentially allowing States to claim sovereign rights to resources in vast maritime areas beyond their immediate coasts, not just in the 12 nautical mile territorial sea that many countries had already declared. Well before UNCLOS III began in 1973, a number of Latin American States

fronting the Pacific and Atlantic Oceans had adopted 200 nautical mile exclusive fishing zones. ${ }^{14}$ Some countries had also claimed a substantial area of continental shelf based primarily upon the 1958 Geneva Convention on the Continental Shelf. ${ }^{15}$ 
The first global oil crisis came in October 1973, just two months before the first session of UNCLOS III convened in December. ${ }^{16}$ The oil crisis increased the eagerness of littoral countries to secure clear rights to potential offshore hydrocarbon resources.

While not directly correlated with the above, immediately after the end of the first session of UNCLOS III, a military engagement took place between the naval forces of China and the Republic of (South) Viet Nam in the waters near the Paracels, which resulted in the establishment of Chinese control over all of the Paracel Islands. ${ }^{17}$ The islands were mostly uninhabited and had little economic value except as bases for fishing. Nevertheless, China and South Vietnam may both have believed that the Paracels could provide a basis for claiming sovereign rights to resources under the adjacent continental shelf and in huge water zones.

The decision at UNCLOS III with the most immediate and far-reaching effect was the adoption of the $200 \mathrm{~nm}$ EEZ within which coastal States gained sovereign rights to explore and exploit, conserve and manage the natural resources (although with full and unimpeded freedom of navigation), and that continental shelf rights in the seafloor also existed out to at least $200 \mathrm{~nm}$ from shore. ${ }^{18}$ The Convention assured that if certain geomorphological and geological criteria were met that States had shelf rights also beyond $200 \mathrm{~nm} .{ }^{19}$ There was strong international support for the $200 \mathrm{~nm}$ EEZ and continental shelf, which had its background in the Latin American fishery zone claims, yet it was surprising that agreement could be reached on such a radical principle, which subsumed a great part of the world's oceans to exclusive national resource jurisdiction. It was clear that the $200 \mathrm{~nm}$ EEZ regime was going to generate conflict in areas where the distance between opposite national coasts is less than 400 nautical miles and more obviously in semi-enclosed seas surrounded by many States and populated by islands subject to sovereignty disputes. 
How did the legal developments during UNCLOS III, and particularly the new regime of the $200 \mathrm{~nm}$ EEZ and continental shelf, affect State behavior in the South China Sea?

Shortly after a 1969 UN report was issued that indicated a vast hydrocarbon potential in the offshore areas of Southeast and East Asia and during the negotiation of UNCLOS III, military troops were sent by the Philippines, Vietnam, and Malaysia to occupy the largest of the insular features scattered around the huge Spratly area. Although no similar actions were taken by China or Taiwan, Taipei continued to maintain its base on Taiping Dao (Itu Aba), the biggest of the Spratlys.

There is little doubt that the eagerness to ensure control of these features was tied to hydrocarbons and the new maritime zones under discussion at UNCLOS III. Between 1970 and 1980, the Philippines occupied Nanshan Island, Flat Island, Thitu Islands, Loaita Island, Northeast Cay, West York Island, Panata, and Commodore Reef. Between 1973 and 1978, Vietnam occupied Nam Yit Island, Southwest Cay, Sandy Cay, Spratly Island, Sin Cowe Island, Amboyna Cay, Grierson Reef (a sand bank sometimes called East Sin Cowe Island), Central Reef, and Pearson Reef. Malaysia followed up by occupying Swallow Reef and Ardasier Reef in 1977 and Mariveles Reef in 1979 (See Table 1). A number of oil exploration contracts were awarded to foreign companies by Vietnam and the Philippines in 1973 and $1974 .^{20}$ In February 1974, in response to acts taken by Taiwan to reinforce its garrison on Taiping Dao (Itu Aba) and the occupation of a number of islands located in the Spratlys by South Vietnam, the Philippines reconfirmed its claim to the area called Kalayaan (Freedomland) and filed formal protests with South Vietnam and Taiwan. Tensions escalated and a military confrontation between South Vietnam, the Philippines and Taiwan seemed imminent. But, according to Marwyn S. Samuels, this was avoided because of a shared fear of a Chinese attack, and US pressure on Saigon. ${ }^{21}$ 


\section{[INSERT TABLE 1]}

In January and February 1974, in response to the actions taken by South Vietnam to occupy a number of land features in the Spratlys, the Chinese Foreign Ministry issued statements, reiterating that:

The Nansha [Spratly] islands, Xisha (Paracel) Islands, Zhongsha [Macclesfield Bank] Islands and Dongsha [Pratas] Islands, are all part of Chinese territory. The People's Republic of China has undisputable sovereignty over these islands and their surrounding area. ${ }^{22}$

The Foreign Ministry of South Vietnam responded by issuing a white paper in February 1975

(two months before the fall of Saigon to North Vietnamese forces), in which Vietnam claimed ownership of Hoang Sa (Paracel) and Truong Sa (Spratly) Islands, and stated that:

The Government of the Republic of Vietnam and the Vietnamese people, determined to defend their sovereignty and the territorial integrity of the country, solemnly denounce the occupation of these Vietnamese territories by foreign troops. Regarding the Hoang Sa (Paracel) Islands, not only was the gross violation of Vietnamese sovereignty by the People's Republic of China a defiance of the law of nations and the Charter of the United Nations: in-as-much as this involved the use of force by a world power against a small country in Asia, it also constitutes a threat to peace and stability in South East Asia. In the case of the Truong Sa (Spratly) Islands, although foreign occupation was not preceded by bloodshed, it nevertheless represents a grave violation of the territorial integrity of the Republic of Vietnam. The rights of the Vietnamese people over those islands have been as firmly established there as on the Hoang Sa archipelago. ${ }^{23}$

In September 1975, China sent a diplomatic note to the Democratic Republic of Vietnam, by then in control of the whole national territory, reminding it of China's sovereignty over the Paracel and Spratly Islands. ${ }^{24}$ In the same month, Deng Xiaoping, then Vice Prime Minister, told a Vietnamese delegation visiting Beijing - according to a Vietnamese source - that "the Paracels and the Spratlys will be our future topics for discussion." 25

In June 1978, assumingly motivated by progress made at UNCLOS III towards establishing a specific legal regime of the EEZ and partly in response to the declarations issued 
by China and Vietnam to assert sovereignty over the Spratly Islands, the President of the Philippines issued a proclamation declaring ownership of those islands situated within the defined boundaries of the Kalayaan Island Group:

[T] hese areas do not legally belong to any state or nation but, by reason of history, indispensable need, and effective occupation and control established in accordance with the international law, such areas must now be deemed to belong (to) and (be) subject to the sovereignty of the Philippines ... while other states have laid claim to some of these areas, their claims have lapsed by abandonment and cannot prevail over that of the Philippines on legal, historical, and equitable grounds. ${ }^{26}$

This proclamation was followed by another Presidential Decree, establishing an EEZ for the Philippines outside its archipelagic waters. ${ }^{27}$

Also likely motivated by the foreseeable outcomes at UNCLOS III, the newly established Socialist Republic of Vietnam issued a declaration on its territorial sea, contiguous zone, EEZ and continental shelf in May 1977, shortly before it became a member of the United Nations. ${ }^{28}$ Much of the wording of the declaration was taken verbatim from the negotiating text issued by UNCLOS III in 1976.

In April 1979, at a meeting between Chinese vice foreign minister Han Nianlong and his Vietnamese counterpart, the Chinese side made the following statement:

The Xisha Islands and Nansha Islands have always been an inalienable part of Chinese territory. The Vietnamese part should come back to its original position of recognizing that fact, respect China's sovereignty over these two sets of islands, and withdraw all its personnel from those islands of the Nansha Islands which it occupies. ${ }^{29}$

China, however, did not take any steps to invade or occupy the Vietnamese held islands in the Spratly area, although China and Vietnam were heading for a bloody war at their land border. The reason why China did not challenge Vietnam militarily in the Spratlys was probably its lack 
of naval capacity and a concern that it might be impossible to defend isolated islets or reefs against a determined counter-attack.

In 1979, China granted seismic survey blocks in the not yet delimitated Beibu (Tonkin) Gulf to a number of Western oil corporations and signed contracts with 48 foreign oil companies to conduct maritime surveys far beyond its coast, signaling its intention to expand its maritime zones into the South China Sea. ${ }^{30}$ In September, the Chinese Foreign Ministry issued a statement, reiterating the government's position on its sovereignty over the Paracel and Spratly Islands as well as their surrounding sea areas and also emphasizing that: "the nature resources in these areas are China's property." 31 This was followed by an official document entitled "China's Sovereignty over the Xisha and Nansha Islands Indisputable" issued by the Chinese Foreign Ministry on 30 January $1980 .^{32}$ The document cited historical and cultural evidence to support the position that the Paracel and Spratly Islands had been under Chinese sovereignty since no later than the Song Dynasty. In 1981, in response to the Chinese document, the Vietnamese Ministry of Foreign Affairs published a booklet entitled "The Hoang Sa and Truong Sa Archipelagoes: Vietnamese Territories" reiterating the position made in a previous booklet in 1979, that "Vietnam has been in possession of the two archipelagoes of Hoang Sa and Truong Sa since the time when no other countries claimed sovereignty over them," and that "Vietnam has been continuously exercising its sovereignty over these two archipelagoes ever since.”33 ${ }^{, 2} 1979$, Taiwan's Executive Yuan (Cabinet) declared the establishment of a $200 \mathrm{~nm}$ EEZ and claimed the sovereign rights over the continental shelf contiguous to its coast as recognized by the 1958 Continental Shelf Convention and general principles of international law. ${ }^{34}$ The declaration did not, however, specify if the ROC claimed an EEZ and continental shelf around any or all of the Spratlys. Malaysia declared the outer limits of its continental shelf in 1979 and an EEZ in $1980 .^{35}$ 
Maritime zone claims were also made by other South China Sea littoral States not involved in disputes over sovereignty to islands. In 1978, the Ministry of Foreign Affairs of Cambodia issued a statement reaffirming its claim to exclusive sovereign rights to all the natural resources within its EEZ and continental shelf and, in addition, claimed that all of its islands have a territorial sea, contiguous zones, EEZ and continental shelf. ${ }^{36}$ In 1980, Indonesia and Singapore both issued a claim to a $200 \mathrm{~nm}$ EEZ, in Indonesia's case measured from its archipelagic baselines. ${ }^{37}$ Thailand claimed a continental shelf in 1973 without defining its limits - just as UNCLOS III began - and an EEZ in 1981, the year before the Convention was adopted. ${ }^{38}$ Bilateral maritime boundary agreements were signed between some of the Southeast Asian States, or between them and external countries, such as Australia, India and Papua New Guinea. $^{39}$ However, no maritime boundary agreements were concluded during this time period concerning any part of the South China Sea itself.

During the negotiations at UNCLOS III, there were repeated claims and counter-claims to ownership of islands and maritime rights in the South China Sea, in particular by Vietnam, China, and the Philippines and, as mentioned, a naval battle took place in the Paracels. There were no bilateral negotiations between claimant States. Clearly, the codification and progressive development of the law of the sea played a role in stimulating the actions taken by the States in claiming and protecting their perceived sovereign rights. Accordingly, the answer to the question concerning whether the LOS Convention exacerbated maritime disputes in the South China Sea by encouraging conflicting claims during this period is a clear yes.

This answer must, however, be qualified. UNCLOS III only contributed to an already existent scramble among the States to strengthen their claims of sovereignty over the South China Sea islands. The 1970 s and early 1980 s scramble cannot be attributed principally to UNCLOS III. There had been similar scrambles before, in the 1930s for strategic reasons, and in 
1956 when there was first an expectation of finding oil. ${ }^{40}$ The new features in the 1982 LOS Convention were not known when the scramble commenced in 1973 or when China used force to take full control of the Paracels in January 1974. The likelihood that a consensus might emerge on a $200 \mathrm{~nm}$ EEZ became clear only during 1975. However, the new $200 \mathrm{~nm}$ EEZ regime raised the stakes and made the sovereignty disputes in the South China Sea more salient and even more difficult to manage or resolve than before.

The answer whether UNCLOS III helped to manage or resolve conflicts in the South China Sea is an equally clear no. This may be ascribed to the fact that the LOS Convention was only in the making. The negotiations opened new opportunities for making national claims to sovereign rights over ocean space and resources and the LOS Convention itself, could only be expected to become a tool for conflict resolution at a later stage.

The main impact of the new legal developments evident during UNCLOS III was to raise the stakes and exacerbate tension by encouraging States to make claims that overlapped, as well as by increasing the perceived salience of small island features in the Paracels and Spratlys. While China took control of the Paracels in January 1974, the main activists in the Spratly area were Vietnam and the Philippines, who, as noted above, occupied a number of previously unoccupied islets. Taiwan and China did not take part in the Spratly scramble, although both Taipei and Beijing publicly confirmed their claims to all of the Spratly Islands. In spite of the peace-making rhetoric in connection with the signing of the LOS Convention and its provisions for peaceful conflict resolution and cooperation, it is difficult to see that the emerging Convention had any significant peace-making effects during the 1973-1982 period. It can be argued though that if UNCLOS III had not led to the adoption of the $200 \mathrm{~nm}$ EEZ, the prospect of finding oil would at any rate have led to a scramble since continental shelf rights had been 
established well before UNCLOS III beginning with the Truman Proclamation in September 1945 and that led to the 1958 Continental Shelf Convention. ${ }^{41}$

\section{Impact of the Adoption of the LOS Convention, 1982-1994}

The LOS Convention adopted in April 1982 and opened for signature in December, entered into force on 16 November 1994. During these 12 years, a number of actions were taken by the South China Sea States, aimed at supporting their claims or weaken the claims of others. These actions included the ratification of the LOS Convention, the deployment of military troops to additional features in the Spratly area, the enactment of domestic maritime legislation, and the signing of contracts with foreign companies to explore and exploit hydrocarbons. A naval battle took place between China and Vietnam in the Spratly Islands in March 1988 after China had established a physical presence in the previous year. The possibility of an armed conflict between these two countries remained high at least until they normalized their relations in 1991. To what extent were the many actions in the period affected by the newly completed LOS Convention and the expectation of its entrance into force? Did the Convention have any positive effect in terms of conflict resolution or management?

In 1987 China completed a geophysical survey of the seabed in the area between and surrounding the Spratly Islands. The survey suggested that the geological conditions were such that the area might contain exploitable reservoirs of oil and gas. ${ }^{42}$ Also in 1987, China decided to separate Hainan Island from Guangdong Province, making it a province in its own right and declared the Spratly Islands to be its "strategic border."43 It was apparent that China was ready to move into the Spratly area. An invitation received from the United Nations Education, Scientific and Cultural Organization (UNESCO)'s Intergovernmental Oceanographic Commission (IOC) for the establishment of five observation posts as part of the Organization's worldwide ocean survey project provided the opportunity. Specifically in March 1987, the IOC 
entrusted China with the task of building an observation station in the Spratly Islands. ${ }^{44}$ China chose Yongshu Jiao (Fiery Cross Reef) and began construction of the necessary infrastructure. In response, Vietnam dispatched cargo ships with construction materials to the same reef, apparently seeking to build structures to underpin its claim. Fiery Cross Reef is located near other islands occupied by Vietnam. A number of small incidents took place in January-February 1988. On 13-14 March, when Chinese and Vietnamese troops apparently engaged in a contest for taking possession of a $5 \mathrm{~km}$ long and $400 \mathrm{~m}$ wide reef, Chigua Jiao (Johnson South Reef) of which only a tiny part was above water, fighting broke out and naval ships of the two countries exchanged fire. The Chinese warships sank all the Vietnamese ships within half an hour with an estimated 74 Vietnamese soldiers either killed or drowned. As a result of the naval battle, China proceeded by the end of 1988 to occupy six reefs and atolls in the Spratly area. ${ }^{45}$ Just as in January 1974, China had used force, but it did not this time evict the Vietnamese from any feature occupied by Vietnam. China instead moved into nearby reefs, and the battle apparently took place when troops from the two countries arrived simultaneously at a submerged reef. Thus, China did not violate the UN Charter as would appear to have been the case in 1974. On the other hand, it is of questionable legality that a State can claim and occupy a submerged reef, which is usually considered to be a part of the seafloor. ${ }^{46}$

In April 1988, China accused Vietnam of preparing for war in the Spratlys. ${ }^{47}$ A month later, it was reported that there were 20 Chinese and 30 Vietnamese warships in the area. ${ }^{48}$ In March 1989, a Spratly Front Line Headquarters was established by China to command a patrol mission. ${ }^{49}$ In August 1989, China placed "sovereignty markers" on six features. ${ }^{50}$ In September 1989, the Chinese Ministry of Foreign Affairs officially demanded the withdrawal of all Vietnamese forces from the Spratly Islands. ${ }^{51}$ It was reported that the Chinese navy was preparing to take action, however, no action was taken mainly, it was claimed, because of a 
shortage of funds, but more probably because of a desire to avoid further international isolation after the "June Fourth Incident" (at Tiananmen Square). ${ }^{52}$ It has also been claimed that action was delayed by Soviet leader Mikael Gorbachev's visit to Beijing in June 1989. The Soviet Union was still Vietnam's ally and Vietnam was just about to withdraw its troops from Cambodia as part of an international effort to end the Third Indochina War.

The Sino-Vietnamese crisis in the Spratlys marks the last outright military confrontation that has taken place in the South China Sea. None of the many later incidents have involved direct fighting between military forces.

In August 1990, in an effort to allay ASEAN's fear over Beijing's entry into the Spratly area, Premier Li Peng declared that: "China is ready to join efforts with Southeast Asian countries to develop the Spratly Islands, while putting aside for the time being the question of sovereignty." ${ }^{, 53}$ The same proposal was restated by the Chinese delegation to the Managing Potential Conflicts in the South China Sea workshop in Bandung, Indonesia in July $1991 .^{54}$ This “Track 2" workshop process had been initiated by Indonesia in the previous year, with participation from all the South China Sea countries, including both China and Taiwan. The Indonesian initiative marked a transition of the South China Sea issues to a phase where the law of the sea became a shared frame of reference in attempts to establish cooperation in a number of domains and to institute conflict prevention mechanisms. This more cooperative atmosphere evolved in conjunction with the end of the Cold War and of the Third Indochina War, just 3-4 years before the LOS Convention entered into force, and just as China was ready to follow the example of the ASEAN countries by enacting EEZ and continental shelf legislation.

China's 1992 legislation and oil concessions, however, led to renewed tension. On 25 February 1992, the Chinese People's Congress enacted the Law of the People's Republic of China on the Territorial Sea and the Contiguous Zone. ${ }^{55}$ Article 2, which provides that the "land 
territory of the People's Republic of China includes the mainland of the People's Republic of China and ... all islands appertaining there to including ... the Dongsha [Pratas] Islands; the Xisha [Paracel] Islands; the Zhongsha Islands [Macclesfield Bank] and the Nansha [Spratly] Islands..." was followed by a contract signed between China's National Offshore Oil Company (CNOOC) and the Crestone Energy Corporation of the United States in an area near Vanguard Bank (Wan'an Tan) in the westernmost part of the Spratlys. This Chinese concession partly overlapped with existing Vietnamese granted oil blocs. ${ }^{56}$ The Vietnamese Foreign Ministry protested the Chinese action, saying that the contract "seriously violated Vietnam's sovereign rights over its continental shelf and exclusive economic zone." ${ }^{, 57}$ In reaction, China warned that it would use its navy, if necessary, to enforce the contract. ${ }^{58}$ About two months later, China further raised the stakes by placing a "sovereignty marker" on Gaven Reef (Nanxun Jiao) just southwest of Itu Aba (Taiping Dao). ${ }^{59}$

In response to the Chinese actions, the Philippines obtained support from the other member States of ASEAN to adopt a Declaration on the South China Sea at the $24^{\text {th }}$ ASEAN Ministerial Meeting in July 1992, which emphasized the need to settle all sovereignty and jurisdictional issues by peaceful means, without resort to force and urged all parties concerned to exercise restraint with the view to creating a positive climate for the eventual resolution of all disputes. ${ }^{60}$ The Declaration further agreed to pursue selected areas of cooperation in the South China Sea without prejudicing the sovereignty and jurisdiction of countries having direct interests in the area and that the principles in the 1976 Treaty of Amity and Cooperation in Southeast Asia could be the basis for establishing a code of international conduct for the South China Sea. ${ }^{61}$ China was asked to subscribe to this Declaration, but it chose not to. In the same month, it was reported that China had deployed two warships to the Spratly area to prevent Vietnam from resupplying a rig which was drilling in a corner of the Crestone contract area. ${ }^{62}$ 
In July 1994, when ratifying the LOS Convention, a number of declarations were made concerning the Paracel and Spratly Islands, including the following statement, which is interesting because it made a clear distinction between the question of sovereignty to islands, and the delimitation of maritime zones.

The National Assembly reiterates Viet Nam's sovereignty over the Hoang Sa [Paracel] and Truong Sa [Spratly] archipelagoes and its position to settle those disputes relating to territorial claims as well as other disputes in the Eastern Sea [South China Sea] through peaceful negotiations in the spirit of equality, mutual respect and understanding, and with due respect of international law, particularly the 1982 United Nations Convention on the Law of the Sea, and of the sovereign rights and jurisdiction of the coastal States over their respective continental shelves and exclusive economic zones; the concerned parties should, while exerting active efforts to promote negotiations for a fundamental and long-term solution, maintain stability on the basis of the status quo, refrain from any act that may further complicate the situation and from the use of force or threat of force.

The National Assembly [differentiates] between the settlement of the dispute[s] over the Hoang Sa and Truong Sa archipelagoes and the defense of the continental shelf and maritime zones falling under Viet Nam's sovereignty, rights and jurisdiction, based on the principles and standards specified in the 1982 United Nations Convention on the Law of the Sea. ${ }^{63}$

Based on the actions taken by the South China Sea claimant States between 1982 and 1994, it can be concluded that the finalization of the LOS Convention and the expectation of its entry into force encouraged conflicting claims and motivated China to enter the scramble for occupation of features in the Spratly area. This led to the 1988 naval battle with Vietnam. However, a transition occurred. All of the claimant States began to refer to the LOS Convention not only as a basis for its claims, but also as a reason for putting aside the sovereignty disputes while "jointly developing" the resources of the area, instituting cooperative mechanisms, managing the conflicts peacefully, abstaining from occupation of any further features, and considering the development of a code of conduct. While China was an eager proponent of the general principle of joint development, Indonesia took upon itself the hosting of the annual Managing Potential Conflicts in the South China Sea workshops, and the Philippines took the 
initiative to establish an international code of conduct. In addition, Vietnam urged settlement of the South China Sea disputes through peaceful negotiations and with due respect for international law and made a clear distinction between sovereignty claims to islands and the delimitation of maritime zones. The importance of the LOS Convention in helping manage and resolve the South China Sea disputes was thus recognized, although progress was exceedingly slow and mixed with continued outbursts of tension.

\section{Impact of the Entry into Force of the LOS Convention, 1995-2002}

The Philippines and Indonesia ratified the LOS Convention in May 1984 and February 1986, long before it entered into force on 16 November 1994. Vietnam became a party in July 1994. Two years later, in June, October, and November 1996, China, Malaysia, and Brunei followed suit. Thus, by the end of 1996, all of the countries involved in territorial disputes in the Paracel and Spratly Islands, with the exception of Taiwan, had ratified the LOS Convention.

It might have been hoped that entry into force of the LOS Convention for the majority of the countries bordering the South China Sea would contribute to the "strengthening of peace, stability, cooperation and friendly relations among all nations." ${ }^{\text {"64 }}$ This did not happen. Actions taken by the South China Sea countries in implementing the LOS Convention, including the adoption of domestic maritime legislation, gave rise to conflict. At the same time, however, the role of the LOS Convention in managing conflicts in the South China Sea was increasingly recognized and the claimant States regularly pledged to live up to their obligation to resolve disputes by peaceful means at important regional security dialogue meetings, such as the ASEAN Summits, ASEAN Ministerial Meetings and the ASEAN Regional Forum (ARF).

In February 1995, shortly after the Convention entered into force, the Philippines discovered that China had built structures on Mischief Reef some $113 \mathrm{~nm}$ from the coast of Palawan. The Philippines launched strong protests against the Chinese action and the Philippine 
Senate passed a bill to modernize the country's armed forces. ${ }^{65}$ In March 1995, the ASEAN foreign ministers issued a statement in support of the Philippines, expressing their "serious concern over recent developments which affect peace and stability in the South China Sea."${ }^{, 66}$ The United States responded with a comprehensive official statement on the Spratly Islands and the South China Sea on 10 May 1995 stating that the United States would view with serious concern any maritime claim, or restriction on maritime activity, in the South China Sea that was not consistent with international law, including the LOS Convention. ${ }^{67}$ The United States, however, was careful not to take any position on the sovereignty disputes or overlapping ocean claims.

At a meeting with the foreign ministers of the ASEAN countries in July 1995, China's foreign minister Qian Qichen proposed, for the first time, to hold bilateral talks with concerned countries to resolve disputes in the South China Sea in accordance with international law. He urged that all of the claimants abide by those principles under international law that govern State-to-State relationships and the peaceful settlement of international disputes in order not to complicate or enlarge the Spratly issue. In addition, he pointed out that the Chinese proposal to "shelve disputes and facilitate joint development" formed the most realistic and practical way forward. ${ }^{68}$

In August 1995, delegations from China and the Philippines met for consultations on the South China Sea and on other areas of cooperation and agreed to adopt a bilateral code of conduct in the South China Sea. ${ }^{69}$ Pending resolution of the sovereignty disputes, the two countries agreed to abide by a number of principles, notably to settle their bilateral disputes in accordance with the recognized principles of international law, including the LOS Convention. This was followed by the adoption of another bilateral code of conduct between the Philippines and Vietnam in November 1995, in which the two sides also agreed to abide by the principle of 
solving their disputes on the basis of respect for international law. ${ }^{70}$ In December 1995, at the $5^{\text {th }}$ ASEAN Summit, held in Bangkok, it was stated that:

ASEAN shall seek an early, peaceful resolution of the South China Sea dispute and shall continue to explore ways and means to prevent conflict and enhance cooperation in the South China Sea consistent with the provisions of the TAC and the ASEAN Declaration on the South China Sea of 1992 as well as international law including the United Nations Convention on the Law of the Sea. ${ }^{71}$

Meanwhile the LOS Convention continued to provide an impetus for making new or reinforcing existing maritime zone claims in the area. In August 1995, Thailand proclaimed the establishment of a contiguous zone. ${ }^{72}$ In August 1996, Indonesia adopted an Act to stipulate the boundaries between its inland waters, archipelagic waters, and the $12 \mathrm{~nm}$ territorial sea outside of its archipelagic baselines. ${ }^{73}$ In June 1996, when it ratified the LOS Convention, China reaffirmed its sovereignty over all its archipelagoes and islands, including the Paracels and Spratlys, as listed in Article 2 of the 1992 Law on the Territorial Sea and Contiguous Zone. ${ }^{74}$ China also promulgated the location of straight baselines and the outer limit of part of its territorial sea adjacent to the mainland, to Hainan Island, and those of the territorial sea adjacent to its controversial archipelagic baselines around the Paracel Islands. ${ }^{75}$ In response to the Chinese claim, the Philippines stated:

China's action in a disputed part of the South China Sea disturbs the stability of the area, sets back the spirit of cooperation that has been slowly developing in the South China Sea and does not help in the resolution of the disputes there. The Philippines calls upon China to confer with other parties to the disputes in the South China Sea with a view to settling their differences in a friendly manner on the basis of equality and mutual respect. ${ }^{76}$

Vietnam also objected to China's baselines in a note verbale dated 6 June 1996 in which it asserted that the baselines around the Paracels constituted a serious violation of Vietnamese sovereignty, that China had violated the LOS Convention by giving the Paracels the status of an archipelago (although China is not an archipelagic State) in order to illegally annex a vast sea 
area into its internal (or archipelagic) waters, and that China had failed to comply with the provisions of the LOS Convention, in particular, Article 7 (straight baselines) and Article 38 (right of transit assage). ${ }^{77}$

In July 1996, Indonesia sent the Chinese Embassy in Jakarta an aide memoire seeking clarification of the Chinese territorial claims in the South China Sea. ${ }^{78}$ ASEAN raised the same question during a dialogue between its seven member countries and China on 29 July 1996. China was asked to explain why it drew straight baselines around the disputed Paracel Islands, from one outermost point to the other in the way that only archipelagic States can do. ${ }^{79}$ The United States also objected to the Chinese baseline claim through a publication issued by the Department of State in July $1996 .{ }^{80}$ The United States noted that "[r]egardless of whose sovereignty the Paracel Islands come under, straight baselines cannot be drawn," since the LOS Convention "is quite clear in stating that an archipelagic State "means a State constituted wholly by one or more archipelagos and may include other islands." ${ }^{81}$ In September 1996, it was reported that "the United States has implicitly warned Beijing that it will not respect a formal Chinese declaration that would restrict freedom of movement by American warships and military aircraft in Asian waters."

Island disputes between China and the Philippines flared up again in May 1997 when Beijing warned that the raising of a Philippine flag on Scarborough Shoal (Huangyan Dao) in the South China Sea was "a serious violation" of its sovereignty. China claimed that Scarborough Shoal "belongs to its Zhongsha Islands (Macclesfield Bank) and is not at all a disputed island." 83 Two years after the ratification of the LOS Convention and declaration of the straight baselines, China enacted the Law of the People's Republic of China on the Exclusive Economic Zone and the Continental Shelf on 26 June $1998 .^{84}$ Article 2 establishes a $200 \mathrm{~nm}$ EEZ, extending from the same baselines from which the breadth of the territorial sea is measured. The 
same article defines China's continental shelf as being the seabed and subsoil of the submarine areas that extend beyond its territorial sea, throughout the natural prolongation of its land territory, to the outer edge of the continental margin (or to a distance of $200 \mathrm{~nm}$ from the baselines where the outer edge of the continental margin does not extend up to that distance). Article 2 also provides that the delimitation of the EEZ and the continental shelf between China and its opposite or adjacent states shall be effected by agreement on the basis of international law and in accordance with the equitable principles. All of this is in accordance with the LOS Convention. More controversially, under Article 14, China indicated that no provisions of the Law "can prejudice historical rights" of China. ${ }^{85}$ China did not clarify the meaning of "historic rights," and whether or not they may be compatible with recognizing other countries' EEZ and continental shelf rights. China also left open the possibility to claim an EEZ and continental shelf around both the Paracels and Spratly Islands. Such an EEZ and continental shelf claim could overlap to a great extent with the EEZ and continental shelf claims of the Philippines, Malaysia, Brunei and Vietnam.

In early November 1998, the Philippines sent a protest after discovering that Chinese warships were stationed in waters not far from islands claimed and occupied by the Philippines and that the Chinese had been constructing new concrete buildings on Mischief Reef, in addition to solidifying those built in $1995 .{ }^{86}$ In February 1999, according to a report containing photographs and other intelligence, China was building a fuel-storage facility next to the airstrip on Woody Island in the Paracels. Some US military officials believed that the fuel depot was built for Su-27s or future Chinese FB-7 fighter bombers to increase the range of the jets and allow them to reach the Spratlys. ${ }^{87}$ Also in February 1999, the Philippines defense secretary Orlando Mercado said that China had built what appeared to be a helipad, radar facilities and possible gun emplacements on Mischief Reef. ${ }^{88}$ 
In June 1999, Malaysia set up structures on Investigator Shoal, which is about $80 \mathrm{~nm}$ adjacent to Sabah. In August, Malaysia built structures on Erica Reef, northwest of Investigator Shoal and northeast of Mariveles Reef. In September 1999, a senior Philippines defense official said that Vietnam was upgrading its structures on Cornwallis South Reef and Alison Reef in the middle of the Spratly area and that Taiwan was improving its military structures on Itu Aba (Taiping Dao). ${ }^{89}$ In October 1999, the Philippines government protested Vietnam's enlargement of a two-story octagonal building set up in 1992 on Tennent Reef (Pigeon Reef) into a three-story structure. ${ }^{90}$ In April 2001, a US Navy EP-3 surveillance plane and a People's Liberation Army F-8 jet of China collided over the South China Sea near Hainan. The United States asserted that it was exercising its legal right under international law to fly over China's EEZ. China claimed that the United States was violating Chinese rights in its EEZ. ${ }^{91}$

The intensity of the disputes in the South China Sea continued to rise despite the entry into force of the LOS Convention. However, except for the EP-3 collision with a Chinese fighter jet, which had little to do with the disputes over maritime zones or sovereignty to islands, the increased tension did not lead to any direct military confrontations. Moreover, during the 19952002 period, the usefulness of the LOS Convention for conflict management was repeatedly emphasized by representatives of all the countries at the annual meetings organized by ASEAN. The series of ASEAN meetings involving China from 1995 to 2002 played a significant role in the adoption on 4 November 2002 of the Declaration on the Conduct of Parties (DOC) by the foreign ministers of ASEAN and China at the $8^{\text {th }}$ ASEAN Summit in Phnom Penh. ${ }^{92}$

The DOC reaffirmed the commitment of the parties to the purposes and principles provided in the international agreements such as the LOS Convention and other recognized principles of international law. The Declaration added that the member States of ASEAN and China would avoid undertaking activities that had the potential to complicate or escalate disputes and affect 
the peace and stability in the South China Sea. A significant example was given in the Declaration when it stated that the parties concerned would refrain from "action of inhabiting on the presently uninhabited islands, reefs, shoals, cays, and other features..."93 ${ }^{93}$ The DOC indicates that: freedom of navigation in and over-flight of the South China Sea will be respected; territorial and jurisdictional disputes are to be resolved by peaceful means; efforts are to be undertaken to build trust and confidence; cooperative activities are to be explored or conducted; and consultations/dialogues are to be continued. ASEAN and China also reaffirmed that the future adoption of a legally binding regional code of conduct (COC) in the South China Sea would promote peace and stability in the region and agreed to work towards it. The Declaration contains several important confidence building measures: the holding of dialogue and exchanges of views between defense and military officials; ensuring just and humane treatment of all persons who are either in danger or distress; and notifying on a voluntary basis other parties concerned of any impending joint/combined military exercises conducted in the Spratly/South China Sea region. Pursuant to the Declaration, the parties concerned may explore or undertake cooperative activities respecting: marine environmental protection; marine scientific research; safety of navigation and communication at sea; search and rescue operations; and combating transnational crime, including but not limited to trafficking in illicit drugs, piracy and armed robbery at sea, and illegal traffic in arms.

After the entry into force of the LOS Convention in November 1994, conflicts between the claimant States in the area continued to occur and even grew in intensity. The occurrence of these conflicts was related to the entry into force of the LOS Convention and actions taken by the South China Sea countries to implement the Convention. There were several aspects of the Convention that generated conflict. First, the difference between the Chinese and the US view on the right to conduct naval and aerial military operations within the EEZ of other States was, and 
remains, a constant generator of conflict. ${ }^{94}$ Second, as already noted, the $200 \mathrm{~nm}$ EEZ regime was bound to generate conflict when applied in a semi-enclosed sea. Third, the LOS Convention opened up the possibility that even small islets could generate their own EEZ and continental shelves, if they were deemed to satisfy the criterion in article 121(3) of the LOS Convention, namely the ability "to sustain human habitation or an economic life of their own." As long as it remains undecided if the Spratly and Paracel insular features in whole or in part can generate EEZs and continental shelves of their own, the sovereignty dispute over these islets will continue to appear vital, with the result that it is difficult to see that the conflict resolution potential of the LOS Convention can come into play. It might be argued that the ambiguity of article 121(3) was a necessary condition for the acceptance of the LOS Convention by States with widely diverging interests as far as the capacity for small islands to generate maritime zones is concerned. If the clause had been more specific it might have prevented this part of the Convention from becoming customary international law. While this may be true, it does not detract from the fact that the ambiguity of 121(3) did generate conflict. Its peace-making potential would depend on gradually developing more and more precision through the setting of precedents in bilateral boundary agreements and decisions by the International Tribunal for the Law of the Sea (ITLOS) or the International Court of Justice (ICJ) (such as the latter's verdict in the Nicaragua versus Colombia case in December 2012).

After the Convention's entry into force, its role in managing and resolving conflicts was more often recognized in official statements from the bordering countries than previously, particularly during the drawn-out negotiations leading to the adoption of the DOC, which reduced the level of conflict for some years after 2002.

While a positive development in the period, the DOC was not the most important one, rather it was the December 2000 Sino-Vietnamese Agreement for the Gulf of Tonkin. ${ }^{95}$ This 
Agreement was not only important in itself, but also set possible precedents for other parts of the South China Sea. The Agreement resulted from long and arduous negotiations and is a textbook example of how the LOS Convention's provisions may be used to arrive at an equitable solution. During the negotiations, Vietnam gave up its long-held claim that a straight line drawn on a map attached to the 1887 Sino-French border treaty should continue southward through the Gulf and thus constitute the maritime border. Vietnam had been claiming that all the waters west of that line were Vietnamese "historic waters." When negotiating the Gulf of Tonkin Agreement, China and Vietnam put aside principles derived from the way sovereignty issues are decided on land and instead applied the principles of the law of the sea. They apparently calculated an equidistant line on the basis of distance from their main coasts and then adjusted it to become a more equitable median line by giving partial effect to certain small islands. One of them, the populated Vietnamese island Bach Long Vi, was given not just a $12 \mathrm{~nm}$ territorial sea but also a right to an EEZ. However, given the island's limited size, its effect on maritime delimitation was modest, so its EEZ now extends only $3 \mathrm{~nm}$ beyond the $12 \mathrm{~nm}$ territorial sea. The main reason why the Gulf of Tonkin Agreement was concluded was that China and Vietnam's leaders had made a mutual and public pledge to reach an agreement by 2000 and then entrusted their main legal and other experts with carrying out the pledge. A similar political commitment could be what is needed in other parts of the South China Sea.

\section{Impact of the LOS Convention After the Adoption of the DOC, 2003-2008}

Beijing's decision not to devaluate the Chinese currency during the 1997-1998 Asian financial crisis and the signing of the DOC in November 2002 helped foster closer relations between ASEAN and China, between China and the Philippines, and between China and Vietnam. In October 2003, the heads of State of the member countries of ASEAN and China issued a Joint Declaration on a Strategic Partnership for Peace and Prosperity. ${ }^{96}$ The Declaration expressed an 
intention to implement the DOC and to discuss and plan concrete modes, areas, and projects of follow-up actions. In the same month, China acceded to the Treaty of Amity and Cooperation in Southeast Asia. ${ }^{97}$ Agreement followed on a detailed "Plan of Action to Implement the Joint Declaration on ASEAN-China Strategic Partnership for Peace and Prosperity" on 29 November 2004 with the view of strengthening "the strategic partnership for regional peace, development and prosperity..."98

On 14 March 2005, the China National Offshore Oil Corporation, the Vietnam Oil and Gas Corporation, and the Philippine National Oil Company signed a Tripartite Agreement for Joint Marine Scientific Research in Certain Areas in the South China Sea, in which they agreed to undertake joint maritime seismic activities in an area of 142,886 square kilometers for three years (2005-2008). ${ }^{99}$ In the joint statement of the signing ceremony, the State-owned companies indicated that the agreement would help transform the South China Sea from a sea of conflict into a sea of peace, stability, and cooperation. ${ }^{100}$

In December 2004, the first ASEAN-China Senior Officials' Meeting (SOM) agreed to establish an ASEAN-China Joint Working Group (JWG) to draft guidelines and an action plan for the implementation of the DOC. However, over the next four years, the Group was unable to reach agreement on guidelines mainly because of disagreement over a paragraph that stated: "ASEAN will continue its current practice of consulting among themselves before meeting with China." China insisted that the South China Sea disputes should be resolved by bilateral consultations among relevant parties and not between China and ASEAN as a group. ${ }^{101}$

Tension on the water began to re-emerge in 2007. In April, Beijing accused Hanoi of infringing on China's sovereignty by agreeing with British Petroleum (BP) to exploit natural gas and lay pipelines from the Nam Con Son basin to the Vietnamese shore. Vietnam claimed that Nam Con Son, which is less than $200 \mathrm{~nm}$ from the Vietnamese coast, is on its continental shelf. 
In June 2007, BP announced that it was halting seismic work after China hinted that the company's actions were infringing China's sovereignty. BP later sold its stake in the Nam Con Son gas field to the State-owned Indian ONGC company. In July 2007, a ship belonging to the Chinese navy fired at Vietnamese fishing vessels near the Spratly Islands, injuring five Vietnamese fishermen. In December 2007, Vietnam registered a protest against China's plan to set up a "Sansha City" (an administrative unit) in the Paracels to manage not just the Paracels, but the Spratlys and Macclesfield Bank as well.

Tensions continued to rise in 2008. In June, China asked the US corporation ExxonMobil to withdraw from an exploration deal it had with Vietnam, claiming that the blocks under contract were in Chinese waters and, therefore, constituted a breach of Chinese sovereignty. In August 2008, Taiwan issued a statement reiterating its sovereignty over the Spratly Islands after Datuk Seri Najib Tun Razak, Deputy Prime Minister of Malaysia, led members of the media to Swallow Reef (Pulau Layang-Layang) and proclaimed Malaysia's sovereignty over the disputed island. $^{102}$

\section{VI: From Outer Continental Shelf Submissions to Arbitration, 2009-2013}

In March 2009, the US Navy hydrography vessel Impeccable was in the South China Sea surveying the seabed in areas where Chinese submarines would pass to and from the Sanya base on Hainan Island. The Impeccable was approached by five Chinese vessels approximately $75 \mathrm{~nm}$ south of Hainan Island who attempted to force it to leave the area. ${ }^{103}$ The United States protested, reportedly stating that consistent with international law the US military can conduct activities "in waters beyond the territorial sea of another state without prior notification or consent" including in an exclusive economic zone of another country. ${ }^{104}$ In response, China stated that the US complaint about the harassment of the Impeccable was "totally inaccurate.".105 
China accused the United States of violating international and Chinese law. ${ }^{106}$ The core issue was the interpretation of provisions of the LOS Convention concerning marine scientific research and navigational freedom within the EEZ of a coastal State. The Impeccable incident demonstrated the two countries' conflicting interpretations of Article 58 of the LOS Convention, a difference of opinion that was evident already at UNCLOS III. ${ }^{107}$

In May 2009, before a UN deadline, Malaysia and Vietnam submitted their proposed outer limits of their continental shelf beyond $200 \mathrm{~nm}$ in the South China Sea to the Commission on the Limits of the Continental Shelf (CLCS) a body established by the LOS Convention with the task to review submitted material and make recommendations to the submitting States. ${ }^{108}$ There were two submissions - the joint submission by Malaysia and Vietnam for the southern area ${ }^{109}$ and the submission by Vietnam for the northern area. ${ }^{110}$

China and the Philippines did not make any submissions of their own with regard to the South China Sea, but in response to the Malaysian and Vietnamese submissions, they sent protest letters to the UN, restating their claims to sovereignty over land features and sovereign rights in the sea. A series of communications followed from China, Vietnam, Malaysia, the Philippines, Indonesia, and Taiwan. ${ }^{111}$ The various claims were now for the first time formulated in official communications. On the one hand, this tended to clarify certain issues; on the other, the submissions and protests further exacerbated the well-known disputes.

China's notes verbale of May 2009 made the map with the U-shaped line, which had existed since the 1940s, official and thus opened it to legal scrutiny and commentary. China indicated that it has "indisputable sovereignty over the islands in the South China Sea and adjacent waters, and enjoys sovereign rights and jurisdiction over the relevant waters as well as the seabed and subsoil thereof (see attached map)". ${ }^{112}$ This explanation reflects uncertainty or controversy within China concerning how to interpret the U-shaped line. China may be claiming 
all the waters enclosed by the line as internal or territorial waters based on an historic waters claim or it may claim sovereignty only over the islands and their "adjacent waters," and sovereign rights to natural resources in their EEZs. The wording of the letter to the UN was ambiguous and did not use conventional legal terms. Chinese statements and actions since May 2009 have supported the probably calculated ambiguity as to whether the U-shaped line is meant as a claim just to islands and their maritime zones or to "historical rights" within a larger area. ${ }^{113}$

The Chinese response to the Malaysian and Vietnamese submissions also stated that: "China has indisputable sovereignty over the islands in the South China Sea and the adjacent waters, and enjoys sovereign rights and jurisdiction over the relevant waters as well as the seabed and subsoil thereof' and that the submissions seriously infringed its sovereignty, sovereign rights and jurisdiction in the South China Sea. ${ }^{114}$ As a result, the Chinese note asked the CLCS not to consider the submissions.

Vietnam responded stating that: "China's claim over the islands and adjacent waters in the Eastern Sea (South China Sea) as manifested in the map attached with the Notes Verbale CLM/17/2009 and CLM/18/2009 has no legal, historical or factual basis, therefore is null and void."115 Malaysia responded with a less confrontational argument, stating that the submissions "constitute legitimate undertakings in implementation of the obligations of State Parties to the [LOS Convention], which conform to the pertinent provisions of [the LOS Convention] as well as the Rules of Procedure of the [CLCS]."116

Indonesia, in its response to the Chinese communications, especially the attached map, made clear its view that: "those remote or very small features in the South China Sea do not deserve an exclusive economic zone or continental shelf of their own," and that the map: clearly lacks international legal basis and is tantamount to upset the [LOS Convention] ... Allowing the use of uninhabited rocks, reefs and atolls isolated from the mainland and in the middle of the high sea as a basepoint to generate maritime 
space concerns the fundamental principles of the Convention and encroaches [upon] the legitimate interest of the global community. ${ }^{117}$

The Philippines did not clarify its position on the legal capacity of the islands in the Spratlys to generate maritime zones. However, in August 2009, the Philippines joined China in asking the CLCS not to proceed with the Joint Malaysian-Vietnamese Submission, since it overlapped with areas claimed by the Philippines and also concerned the "controversy" over sovereignty to North Borneo (the Malaysian state of Sabah). ${ }^{118}$ The Chinese and Philippines' notes will prevent the CLCS from considering the Malaysian-Vietnamese submissions.

In April 2011 the Philippines reaffirmed its sovereignty and jurisdiction over all "geological features" in the Kalayaan Island Group, said to encompass 53 islands, reefs, shoals cays, rocks and atolls, and challenged the legitimacy of the Chinese claim to sovereignty, sovereign rights and jurisdiction over these islands, their "adjacent waters", "relevant waters", and seabed and subsoil encircled by the U-shaped line. ${ }^{119}$

In April 2011, in response to the communication from the Philippines, China asserted that "under the relevant provisions of the 1982 United Nations Convention on the Law of the Sea, as well as the Law of the People's Republic of China on the Territorial Sea and the Contiguous Zone (1992) and the Law on the Exclusive Economic Zone and the Continental Shelf of the People's Republic of China (1998), China's Nansha [Spratly] Islands [are] fully entitled to Territorial Sea, Exclusive Economic Zone (EEZ) and Continental Shelf." ${ }^{\text {"20 }}$ It may be presumed that in China's view, the Pratas and Paracel Islands, perhaps even Scarborough Shoal (Huangyan), also have a right to an EEZ and continental shelf beyond $200 \mathrm{~nm}$.

The Malaysian and Vietnamese submissions and the communications that followed clarified the position of the various countries as to the capacity of small features - islands, sandbanks, shoals or rocks - to generate extended maritime zones. Indonesia, Malaysia, and 
Vietnam took the explicit or implicit view that such features can have only $12 \mathrm{~nm}$ territorial waters. China saw them as "fully entitled" to an EEZ and continental shelf of their own. The views of Brunei, the Philippines, and Taiwan are not yet known. However, it seems likely that Brunei, which does not occupy any features in the Spratlys, will agree with Indonesia, Malaysia, and Vietnam. The Philippines seems to be moving in the same direction. By contrast it must be tempting for Taiwan, which occupies Itu Aba/Taiping Dao, the largest of the Spratly islands, and also Pratas Island, to argue that at least those two features can have the full suite of maritime zones. By implication, the same would have to be the case for Woody Island, the largest in the Paracels, although probably not for the very small Scarborough Shoal, which in the view of Taiwan can have only a $12 \mathrm{~nm}$ territorial water zone.

Since 2009, a series of enforcement and other actions have been taken by China apparently to demonstrate its jurisdiction over the South China Sea and these actions appear to pertain to the whole area within the U-shaped line. In March 2009, China sent its largest fishery patrol ship, Yuzheng 311, to the Spratlys for fishery protection and maritime surveillance. ${ }^{121}$ In May 2009, China announced a unilateral three-month moratorium on fishing in the South China Sea from the $12^{\text {th }}$ parallel north of the Spratly Islands up to the Chinese coast. The aim of the moratorium was to preserve fish stocks and prevent illegal fishing. ${ }^{122}$ Since 2009 , China has annually announced a three-month fishing ban, which has given rise to jurisdictional disputes, in particular with Vietnam, concerning the waters surrounding the Paracel and Spratly Islands. China has repeatedly seized Vietnamese fishing boats in waters near the Paracel Islands. ${ }^{123}$ Enforcement actions have also been taken by China in the area west of Palawan in the eastern part of the South China Sea. In February 2011, three Philippines' fishing boats, operating in the waters off Jackson Atoll, $140 \mathrm{~nm}$ west of Palawan, received the following warning from a Chinese warship, reportedly a Jianghu-V Class missile frigate: "You are in [China's] territory. 
Leave the area immediately." 124 The Philippines claims that Jackson Atoll belongs to the Kalayaan Island Group which, under the Philippines' law is part of the country's regime of islands, and that the waters in this area are within the Philippines' EEZ. ${ }^{125}$ In October 2011, in response to the action taken by a Philippines naval vessel against a Chinese fishing vessel that was operating in the waters off Reed Bank (Liyue Bank) of the Spratly archipelago, China's foreign ministry spokesperson Jiang Yu stated that:

China enjoys indisputable sovereignty over the Nansha [Spratly] Islands and their adjacent waters. It is completely justified for Chinese fishermen to fish in an area that has been a traditional fishing ground for generations. The actions taken by the Philippines have harmed the lawful rights and interests of Chinese fishermen. ${ }^{126}$

The Philippines rejected China's statement. ${ }^{127}$

China and Malaysia have been at odds over fishing activities in the waters near Pulau Layang Layang (Swallow Reef) in the southern Spratlys, which has been under Malaysian occupation since the late 1970s. In April 2010, China responded to action taken by Malaysia against Chinese fishing boats by dispatching escort vessels. ${ }^{128}$ There have also been incidents between China and Indonesia. In June 2010, during a stand-off over Indonesia's seizure of a Chinese fishing vessel operating in the waters north of Natuna Island in the southernmost part of the South China Sea, a Chinese maritime surveillance vessel pointed its large-caliber machine gun at a carbon-hulled Indonesian craft, demanding the release of the detained Chinese fishing boat. A similar episode had occurred in the previous month. ${ }^{129}$ These confrontations involving Indonesia occurred in an area within the Chinese U-shaped line that is recognized in formal treaties between Indonesia and Malaysia, ${ }^{130}$ and Indonesia and Vietnam ${ }^{131}$ as being within the Indonesian EEZ..

Since March 2011, there has been a new round of conflict over oil and gas exploration. These disputes not only concern areas near the disputed Spratlys but areas that, although within 
the U-shaped line, are closer to the mainland coasts of Vietnam and the Philippines than to any disputed island. In March 2011, two Chinese marine surveillance vessels ordered the Veritas Voyager, a survey vessel operating on the Reed Bank in the eastern Spratlys near the Philippines, to leave. The survey vessel had been chartered by a UK-based oil and gas company, which had a contract with the government of the Philippines to conduct seismic studies in the area of the Sampaguita gas field. The Philippines protested the Chinese action. ${ }^{132}$ In May and June 2011, Chinese vessels were spotted in the area near Bombay Shoal, Reed Bank and Amy Douglas Bank, reportedly unloading building materials, erecting posts, installing plastic buoys, and placing markers on these low tide elevations and underwater features. These are shallow waters, but it was also reported that China planned to install a new advanced deep sea oil rig. ${ }^{133}$ In response, Lt. Gen. Juancho Sabban, chief of the Philippines' Western Command, asked Filipino fishermen to be ready to use their boats to block the operation of the Chinese oil rig. ${ }^{134}$ On 4 July 2011 , China delivered a protest to the Philippines following Manila's invitation to foreign companies to bid for oil and gas rights in areas northwest of Palawan, claiming that the areas fall under China's "indisputable sovereignty.",135

A similar dispute had arisen between China and Vietnam. In May 2011, a Chinese marine surveillance vessel cut the seismic cables of the Vietnamese ship Binh Minh 02 that was operating in Vietnam's Block 148, about $65 \mathrm{~nm}$ off the coast of Vietnam, and some $325 \mathrm{~nm}$ south of Hainan Island and far away from any Spratly feature. ${ }^{136}$ This was followed by another cable cutting incident in June 2011 near Vanguard Bank in the western-most Spratlys, the same area where Vietnam and China have had overlapping hydrocarbon concessions since 1992. Vietnam interpreted the incidents as a Chinese effort to enforce its U-shaped line claim. ${ }^{137}$

These incidents led to Chinese and Vietnamese officials in October 2011 signing a six-point agreement providing that the two countries would solve their maritime disputes "on the 
basis of legislation and principles enshrined in international law, including the United Nations Convention on the Law of the Sea signed in 1982." Both sides also pledged to "fully respect legal principles" and agreed that their border negotiation teams would have meetings twice a year to negotiate their bilateral differences, while also consulting third parties. ${ }^{138}$ The most important part of the six-point agreement was to reconfirm a 2008 agreement to have bilateral talks about maritime delimitation in the mouth of the Gulf of Tonkin and to restart the talks. ${ }^{139}$ A maritime delimitation agreed upon in the mouth of the Tonkin Gulf may have some interesting implications for the whole of the South China Sea. As noted above, the 2000 agreed boundary inside the Gulf is based on a median line between Hainan and the coast of central Vietnam with some effect being given to Con Co, a small island off the coast of Vietnam. ${ }^{140}$ Vietnam may have to accept a line pointing in a direction that will separate the Paracels from the Vietnamese coast. Vietnam would then have to consider the Chinese-occupied Paracels as a Vietnamese enclave within the Chinese EEZ. This would weaken the Vietnamese Paracels claim. For China, the problem is that if the existing maritime boundary is extended southward from the Tonkin Gulf it will approach the first of the nine dashes of the U-shaped line. Vietnam is unlikely to accept a boundary that coincides with the U-shaped line. An extension of the Gulf of Tonkin maritime boundary may thus clarify that the U-shaped line does not represent a claim to "maritime territory" or "historic waters" but only to the islands inside it and their maritime zones. This would benefit conflict resolution in the South China Sea as a whole.

The prospect of seeing such clarification was given a boost on 29 February 2012, when a spokesperson for the Chinese Foreign Ministry confirmed that there is a distinction between sovereignty to islands and maritime delimitation and added: "No country including China has claimed sovereignty over the entire South China Sea."141 However, it did not take long before China took action pointing in the opposite direction. China protested on 26 October 2011 when it 
was reported that gas had been found by ExxonMobil off the coast of Vietnam, nearer to the Vietnamese coast than to any of the Spratlys, but within the U-shaped line. ${ }^{142}$ On 22 June 2012, Vietnam passed its first national maritime law, which had been under preparation for many years. It asserted Vietnam's sovereignty over the Paracel and Spratly Islands. ${ }^{143}$ Soon thereafter the Chinese National Offshore Oil Company placed nine oil blocks for international tender along the U-shaped line adjacent to the Vietnamese coast overlapping with existing Vietnamese blocks. ${ }^{144}$ A map was published of the Chinese blocks that caused consternation in Vietnam. China also formally approved its plan to elevate "Sansha city" in the Paracels to prefecture status, with responsibility for administering all of the Paracels, the (submerged) Macclesfield Bank, and the Spratlys. ${ }^{145}$ Both Vietnam and the Philippines lodged protests. ${ }^{146}$

This new Sino-Vietnamese crisis followed a globally publicized one between China and the Philippines over Chinese fishing. In early April 2012, the Philippines' largest warship tried to drive away Chinese fishing boats from the waters near Scarborough Shoal/Huangyan, a group of small rocks encircling a lagoon west of Luzon. The shoal as a whole is claimed by China, Taiwan, and the Philippines. If it should come under Chinese or Taiwanese sovereignty and have a $12 \mathrm{~nm}$ territorial sea, then it will form an enclave inside the Philippines' EEZ. The Philippines warship attempted to arrest Chinese fishing boats, but was prevented by two Chinese maritime surveillance vessels. ${ }^{147}$ A standoff followed, that lasted several weeks, with PLA Navy vessels observing from a distance. In the end, bad weather forced the Philippines' warship to withdraw after it apparently got an understanding that the Chinese ships would also pull out. Some Chinese boats remained, however, and the entrance to the lagoon was sealed off. The standoff was seen in China as a big success. Chinese commentators claimed that an astute strategy, using China's superior force to deter the Philippines, had led to a situation of de facto Chinese control. ${ }^{148}$ The Philippines' launched an effort to get the United States to support its sovereignty in the South 
China Sea. Washington responded by upgrading its support to the Philippines, but refrained from taking sides in the legal disputes over Scarborough Shoal and the Spratlys (Kalayaan). ${ }^{149}$

During the Scarborough standoff, there was also tension between Taiwan and Vietnam. In April 2012, a number of Taiwanese lawmakers visited Taiping Dao (Itu Aba) aiming to reaffirm Taiwan's sovereignty over the Spratly Islands. Vietnam lodged a protest against the visit. ${ }^{150}$

While tensions rose, calls to respect international law continued to be made. For example, in July 2010 the $43^{\text {rd }}$ ASEAN Ministerial Meeting welcomed the commitment of all the parties concerned to resolve the disputes through peaceful means in conformity with the spirit of the DOC and the recognized principles of international law, including the LOS Convention. ${ }^{151}$ At the $17^{\text {th }}$ ASEAN Regional Forum, held in Hanoi in July 2010, Secretary of State Hillary Clinton said that the United States, "like every nation, has a national interest in freedom of navigation, open access to Asia's maritime commons, and respect for international law in the South China Sea" and that although "claimants should pursue their territorial claims and accompanying rights to maritime space in accordance with the UN convention on the law of the sea." ${ }^{\prime 152}$

In July 2012, the ASEAN Foreign Ministers $45^{\text {th }}$ meeting in Phnom Penh failed to reach consensus on whether or not to include a specific mention of Scarborough Shoal in their joint statement. Thus, for the first time, the ASEAN Ministers ended the meeting without issuing a joint communiqué. ${ }^{153}$ A majority of the ASEAN member States reportedly supported the Philippines and Vietnam's insistence that Scarborough Shoal be mentioned, but Thailand, Myanmar and the host nation Cambodia were against. Following an Indonesian initiative, on 20 July 2012, the ASEAN foreign ministers issued a six point statement of principles concerning the South China Sea, which included calling for the full implementation of the 2002 DOC and support for guidelines adopted in 2011 for how to implement the DOC, and recognizing the need for an early conclusion of a regional code of conduct, full respect for international law including 
the LOS Convention, the continued exercise of self-restraint and non-use of force by all parties, and the peaceful resolution of conflicts. At the $21^{\text {st }}$ ASEAN Summit in Phnom Penh, 19 November 2012, China and ASEAN made a long joint statement pledging to uphold the DOC fro 2002 and "keep the momentum of dialogue and consultation to enhance trust, confidence and cooperation, and work together for the adoption of a code of conduct in the South China Sea on the basis of consensus." At the $22^{\text {nd }}$ ASEAN Summit in Brunei 24-25April 2013, the heads of state/governments in the member states agreed to look "forward to continued engagement with China in implementing the DOC in a full and effective manner ... [and] ... tasked our Ministers to continue to work actively with China on the way forward for the early conclusion of a Code of Conduct in the South China Sea (COC) on the basis of consensus." 154

Developments since 2008-2009 indicate that this may be difficult. China changed its general approach at that time and pushed more actively its claims to natural resources, both living and non-living, in the whole area enclosed by the U-shaped line. Like the Philippines it did not make any submission to the CLCS concerning the extension of its continental shelf in the South China Sea, although it did so for the East China Sea on 14 December 2012. ${ }^{155}$ The ASEAN members and the United States repeatedly called upon the concerned parties to follow the rules of international law, in particular the law of the sea. In addition, on 22 January 2013, three months before the ASEAN Summit in Brunei, the Philippines took a new dramatic initiative, which was deeply resented in Beijing, so deeply that it now seems to uphold any progress in China-ASEAN talks about a COC. The Philippines, in accordance with Article 287 and Annex VII of the LOS Convention, submitted a request to China to set up an Arbitral Tribunal, which should consist of five members, to decide on issues discussed between Manila and Beijing since 1995. These issues are essential indeed. The Philippines requested that the Arbitral Tribunal should issue an award to the effect that, among other, "China's maritime claims 
in the SCS based on its so-called nine-dash line are contrary to UNCLOS and invalid", and that China must "bring its domestic legislation into conformity with its obligations under UNCLOS." ${ }^{156}$ In accordance with the requirements, the Philippines appointed ITLOS judge Rudiger Wolfrum as a member of the Arbitral Tribunal.

However, like several other countries, China had taken exception from Article 298 on mandatory dispute settlements when ratifying the LOS Convention. In addition, on 25 August 2006, China had declared that it "does not accept any of the procedures provided for in Section 2 of Part XV of the Convention with respect to all the categories of disputes referred to in paragraph 1 (a) (b) and (c) of Article 298 of the Convention."157 Yet the Philippines had established that no country can prevent compulsory arbitration under annex VII of the Convention. The Philippines made its request to China on its own, with no official backing from any other member of ASEAN. On 19 February 2013, China rejected the request and refused to appoint any judge on the Tribunal. Accordingly, in accordance with LOS Convention Annex VII, the President of ITLOS was asked to appoint the four remaining members. In March 2013, ITLOS Polish judge Stanislaw Pawlak was appointed to be China's arbiter and second member of the Tribunal. ${ }^{158}$ This was followed by appointments of the three last members of the Tribunal on 24 April 2013, namely Jean-Pierre Cot of France, Chris Pinto of Sri Lanka, and Alfred Soons of the Netherlands. ${ }^{159}$ Accordingly, the Arbitral Tribunal has been established. When its proceedings begin it must decide if it has jurisdiction over the case, given China's 2006 statement. If it finds that it has not, then it may request of China that it submit the dispute to non-binding conciliation under Annex V of the LOS Convention, and to negotiate an agreement on the basis of the report of the conciliation commission. ${ }^{160}$ If this should fail, then the next would be to revert to binding arbitration under Annex VII. If the Arbitration Tribunal decides to carry through with the case and eventually comes up with a decision that satisfies the Philippines' 
expectations, then this could undermine China's respect for international law and weaken the LOS Convention as an instrument for peaceful dispute resolution. It is, however, also conceivable that the Arbitral Tribunal, even in the absence of Chinese participation, comes up with a decision that China can live with. The mere existence of the Tribunal might moreover persuade China to itself clarify the legal meaning of the U-shaped line and define more precisely which areas of the South China Sea it considers to be disputed. ${ }^{161}$ According to foreign minister Alfred de Rosario the Philippines action is based on 'President [Benigno] Aquino's policy for a peaceful and rules-based resolution of disputes" $" 162$ Regardless of such good intentions it is impossible to say today if the arbitration will weaken or strenghten the role of international law as an instrument of peaceful conflict management and resolution.

\section{Conclusions and Ways Forward}

The article has found that UNCLOS III and the LOS Convention have had ambiguous effects on peace and conflict in the South China Sea. On the one hand the Convention has exacerbated militarized disputes over sovereignty to islands by encouraging overlapping zone claims and failing to resolve key legal issues, notably by holding out the possibility that some of the Spratly, Paracel and Scarborough features may have a right to vast maritime zones. On the other hand, the Convention has obligations, language and techniques for conflict prevention, management and resolution. Some of its most controversial ambiguities may be resolved step-by-step through precedents set by court decisions and bilateral treaties. Through our analysis of four historical periods since UNCLOS III began in 1973, we have found the conflict-enhancing impact of the LOS Convention to have been more substantial overall than the peace-promoting effects. Nevertheless, the balance has shifted over time towards a stronger regional emphasis on conflict management manifested in the 2002 China-ASEAN Declaration on the Conduct of Parties (DOC) and the ongoing attempts to develop a legally binding code of conduct on the basis of the DOC. 
The 2002 DOC probably would not have come about had it not been for the Managing Potential Conflicts in the South China Sea workshops, organized and hosted by Indonesian Ambassador Hasjim Djalal from 1991 onward as track two diplomacy. Constructive utilization of the LOS Convention's peace-making potential has been evidenced in a number of bilateral maritime boundary agreements in peripheral parts of the South China Sea, the Gulf of Tonkin, the Gulf of Thailand, and in the southernmost part of the South China Sea. If these trends continue, and the provisions of the Convention are more rigorously respected and applied by its Parties, its peace-promoting potential will prove stronger than its conflict-enhancing effects. After all, there is no way to resolve the maritime disputes without reference to the LOS Convention. Although the Convention does not offer help to resolve disputes over sovereignty of land features such as islands and rocks, it does provide rules and language that must be used in formulating agreements on maritime delimitation.

It is time to confess to a methodological problem. In discussing the impact of the LOS Convention, little attention has been paid above to the question of what rules would have been in place if there had been no UNCLOS III or LOS Convention. This counter-factual question must be considered to evaluate the impact of the Convention as distinguished from effects of the legal situation before UNCLOS III began and from developments in customary international law that would have occurred without the Convention. If UNCLOS III had not been held or had failed to establish the "Constitution for the Oceans," yet much, if not most, of its contents would have constituted international law. Many of the provisions in the LOS Convention were in the four 1958 Geneva Conventions. Other provisions reflected existing customary international law and, of course, customary law would have continued to develop.

In the context of the South China Sea, the most important regime that might not have been agreed upon had it not been for UNCLOS III, is the $200 \mathrm{~nm}$ EEZ. It was a compromise struck 
between those coastal States that wanted to increase the breadth of the territorial sea beyond 12 $\mathrm{nm}$ and those maritime nations that found it unacceptable to expand sovereignty in such a radical way, yet could endorse a special zone where coastal States would have sovereign rights to the resources, but not general sovereignty or jurisdiction that would interfere with the freedom of navigation. Without the LOS Convention, the conflict that was largely resolved through the EEZ compromise would probably have continued to manifest itself in the form of unilateral national legislation and on-the-water confrontation.

Without the Convention, the international law of the sea might have developed in a similar fashion to what is happening in global trade. The failure of the World Trade Organization's Doha round has led to the emergence of a patchwork - or noodle bowl - of bilateral, regional and cross-regional free trade areas, with a great number of crisscrossing treaty obligations. If there had been no agreement on a $200 \mathrm{~nm}$ EEZ, then State practice most likely would have differed more radically than it does today. Some coastal States would have been expansive, others more cautious, depending on their relationship with the major maritime powers and their own interests. It is difficult to say if, without the LOS Convention, the key issue respecting the capacity of the Spratlys and Paracels to generate an EEZ and continental shelf would have been closer or further away from being resolved. It is, however, difficult to imagine that the risk of armed conflict in the Spratlys would have been reduced by the absence of the LOS Convention. A more volatile legal and political situation would probably have resulted.

Many commentators and political analysts see a dichotomy between law and so-called realpolitik. Whenever States fail to reach agreement on the basis of international law, they claim that realpolitik takes over. Then they compare naval and other military capabilities and assume that the States with the most "hard" power, or those with the strongest allies, will prevail and realize their aims. The study above leads to disagreement with these "realist" assumptions. 
Coercive naval power does not provide a realistic alternative to the application of international law. Not even the strongest of States can force other sovereign States to keep their fishermen away from disputed fishing grounds. Not even the strongest of States can tap oil from basins located in areas claimed by other sovereign States without provoking reactions that endanger the whole enterprise. Even “weak" States would not voluntarily sign away part of their continental shelf through an "unequal treaty" with a militarily superior neighbor. There is simply no realpolitik alternative - short of war - to resolving the South China Sea disputes. The only viable solution is the application of international law.

Of course, the signing and ratification of the LOS Convention did not end legal development of relevant law of the sea. Additional protocols and treaties have been concluded. Through international court decisions and bilateral treaties new ideas and obligations have emerged and customary law has continued to develop. Some of the basic disagreements at the time when the Convention was negotiated have continued to play out. In the South China Sea context, the most important such disagreements concern the extent of the sovereign rights of coastal States in the EEZ vis-à-vis other rights, the legal regime of islands, and the principle of equity in establishing maritime boundaries where EEZ and continental shelf claims overlap.

Interestingly, all the South China Sea States who took active part in UNCLOS III - except Singapore - belonged to the camp of the developing coastal States and shared the same expansionist aims. China, Vietnam, the Philippines, and Indonesia all pushed for extending coastal State sovereignty. Malaysia and Brunei were mainly concerned with protecting their already discovered offshore oil resources. Indonesia and the Philippines obtained the special status as archipelagic States. Singapore, sensitive to a need for combining freedom of navigation with good neighborly relations, played a constructive role in working for compromise solutions. 
Since the 1990s, remarkable changes have taken place, partly due to a better understanding of international law, but mainly because of China's rising power. In spite of a rapid expansion of legal expertise in China, its government and media have generally continued to use the language of the 1980s, often referring to most of the South China Sea as Chinese "maritime territory," claiming sovereignty to features that are not above water at high tide and failing to distinguish between land and water. Meanwhile, the other coastal States of the South China Sea have become increasingly legalistic. Instead of seeking to expand their "maritime territory" beyond the provisions of existing international law, they now aim to consolidate what they achieved through the LOS Convention. Jakarta, Hanoi, Manila and Kuala Lumpur have generally applied and implemented the language and basic provisions of the law of the sea. In view of their wish for a stronger US presence to counterbalance China, they are no longer as eager as they may have been to deny foreign navies access to their territorial seas and EEZ. They have even arrived at the peace-promoting conclusion that none of the island features in the Spratlys are entitled to a continental shelf or EEZ of their own.

While the main claimant States in ASEAN have arrived at a shared understanding, which could realize the peace promoting potential of the LOS Convention, there has been acrimony between them and China, with Taiwan as a more cautious, independent supporter of the "Chinese" position. The tensions have played out in several diplomatic quarrels and incidents during 2010-2013. Hence, the jury is still out concerning the ambiguity respecting of the LOS Convention. Overlapping EEZ claims, conflicting interpretations of article 121(3), and China's "sovereignty" or "historic rights" within the U-shaped line continue to drive conflict. It is impossible to know now what the impact will be of the Philippines' January 2013 request to the UN to set up an ad hoc Arbitration Tribunal to declare the U-shaped line illegal and compel China to oblige by the law of the sea. 
Are there alternative ways out? The two proposals that are heard most often, which are not mutually exclusive, are: a legally binding code of conduct and joint development of the resources. Since 2002 ASEAN and China have held regular talks to discuss a legally binding code of conduct with the ASEAN foreign ministers reportedly agreeing on a draft in $2012 .^{163}$ If this effort is ultimately successful (talks now again seem to be on hold), it can help dampen or even prevent new incidents and create an atmosphere conducive to long-term conflict resolution. Joint resource development may be a good idea where two or more parties can agree that a certain area is disputed. In order for parties to agree that an area is disputed, however, each party must have a legitimate basis for claiming the area. Therefore, before accepting joint development, one needs to narrow the target area to one that both or all sides are willing to consider as disputed. It should be possible to agree that the Spratly islands area, Scarborough Shoal and the $12 \mathrm{~nm}$ territorial sea around each island are disputed. Vietnam also considers the Paracels and their $12 \mathrm{~nm}$ territorial seas as disputed, though China, does not accept any dispute here at all.

If China's 7 May 2009 communication explaining that the attached map with a U-shaped line indicates a Chinese claim to all islands inside "and their adjacent waters" can be understood to mean the islands and the maritime zones they may generate on the basis of the law of the sea, then it should also be possible to agree that any area that is nearer to legitimate Philippines, Malaysian, Brunei or Vietnamese baselines than to any of the Spratly islands, is not under dispute. If this were agreed upon, a large area would still remain disputed between and around the Spratlys, which could perhaps become the focus of joint development projects, but substantial areas of the South China Sea would be free of disputed claims.

Two steps could be taken to further narrow the ocean area subject to dispute. The first could be to ask the Law of the Sea Tribunal (or another third party adjudicative body) to resolve the question of which, if any, of the Spratlys, Paracels and Scarborough Shoal can support 
human habitation or an economic life of their own so they can generate an EEZ and continental shelf. Unless all of the 30-40 Spratly islands are considered to have such capacity, this would lead to adjustments in claimed areas between the Spratlys and the opposite territorial coasts that would further reduce the disputed area. The next step would be to establish an equitable median line between the Spratlys and the opposite coasts of Palawan, Borneo and Vietnam, taking into due consideration the principles of maritime boundary delimitation including the length of the relevant coasts. Such a line is likely to be much closer to the Spratly islands than to the opposite coasts. The problem, of course, with any such narrowing down of the disputed area is that it tends to benefit the ASEAN States rather than China.

Yet China's continued peaceful development, economic growth and global role depends on a peaceful and stable neighborhood. This cannot be obtained through investment, trade and aid only. Neither can it be achieved through coercion. The way forward for China, just as for the other countries around the South China Sea, goes through negotiations, bilaterally and multilaterally, with reference to the law of the sea.

\footnotetext{
${ }^{1}$ U.N. Convention on the Law of the Sea, 1833 U.N.T.S. 397, adopted in Montego Bay, Jamaica, on 10 December 1982, entered into force on 16 November 1994.

2 “A Constitution for the Oceans," Remarks by Tommy T.B. Koh, Singapore, President of the Third United Nations Conference on the Law of the Sea, adapted from statements on 6 and 11 Dec. 1982, available at $<$ www.un.org/depts/los/convention_agreements/texts/koh_english.pdf $>$.

${ }^{3}$ On 12 January 1983, the Republic of China Foreign Minister Chu Fu-sung declared at the $6^{\text {th }}$ plenary session of the Committee on Foreign Affairs of the $7^{\text {th }}$ session of the Legislative Yuan (the Parliament) that "[a]fter the Law of the Sea Convention enters into force, our attitude is that in principle we will comply with its terms." See Kuo-Tsai Chao, "The Republic of China and the Law of the Sea," in The Law of the Sea: Problems from the East Asian Perspective, ed. by Choon-ho Park and Jae Kyu Park, (Honolulu: Law of the Sea Institute, 1987), p. 347.
} 
4 These questions were first discussed in Stein Tønnesson, "International Law in the South China Sea: Does it Drive or Help Resolve Conflict?" paper presented at the $3^{\text {rd }}$ International South China Sea Conference, Hanoi, Viet Nam, 4-5 November 2011, 3 .

${ }^{5}$ The Territorial Sea and Contiguous Zone Convention, 29 April 1958, entered into force 22 September 1964,516 U.N.T.S. 205 and the High Seas Convention, 29 April 1958, entered into force 3 January 1963, 450 U.N.T.S. 11.

${ }^{6}$ See: Bangkok Summit Declaration, Bangkok, 14-15 December 1995, available at <www.aseansec.org/5189.htm>.

${ }^{7}$ Chairman's Statement of the 3rd Meeting of the ASEAN Regional Forum, Jakarta, 23 July 1996, para. iv, available at

<cil.nus.edu.sg/1996/1996-chairman\%e2\%80\%99s-statement-of-the-3rd-asean-regional-forum-issued-on-23-july-19 96-in-jakarta-indonesia/>.

${ }^{8}$ Chairman's Statement of the 6th East Asia Summit, Bali, Indonesia, 19 November 2011, para. 5, available at $<$ www.aseansec.org/documents/19th\%20summit/EAS-CS.pdf $>$.

9 See: Phnom Penh Declaration on ASEAN: One Community, One Destiny, adopted at the $20^{\text {th }}$ ASEAN Summit, Phnom Penh, Cambodia, 3 April 2012, para. 5, available at

$<$ www.aseansec.org/documents/pp_declaration_3\%20April_FINAL.pdf $>$.

10 The 2002 Declaration on the Conduct of the Parties is available at <www.aseansec.org/13163.htm>.

11 Chair's Statement of the 20 ${ }^{\text {th }}$ ASEAN Summit, Phnom Penh, 3-4 April 2012, available at <asean2012.mfa.gov.kh/documents/Chairman_Statement_20th_ASEAN_Summit_FINAL.pdf>.

12 For the Chairman's Statement in 2012: www.presspool.jp/asean/officialdocuments/459991.html, and in 2013: http://www.asean.org/news/asean-statement-communiques/item/chairmans-statement-of-the-22nd-asean-summit-our -people-our-future-together.

13 See: Stein Tønnesson, "The South China Sea in the Age of European Decline," 40 Modern Asian Studies No. 1 (2006), pp. 3-57.

14 These were: Ecuador and Argentina 1966, Panama 1967, Uruguay 1969, Brazil 1970. See: Donald R. Rothwell and Tim Stephens, The International Law of the Sea (Oxford and Portland, Oregon: Hart, 2010), p. 10.

15 The Continental Shelf Convention, 29 April 1958, entered into force 10 June 1964, 499 U.N.T.S. 311.

${ }^{16}$ UNCLOS III held eleven sessions from 1973 to 1982. 
17 For a detailed account, see: Lu Ning, Flashpoint Spratlys! (Singapore: Dolphin, 1995), pp. 74-86. See also

"Battle of the Paracel Islands," Wikipedia, available at <en.wikipedia.org/wiki/Battle_of_the_Paracel_Islands>; Marwyn Samuels, Contest for the South China Sea, (New York: Methuen, 1982), pp. 98-117; David Muller, China's Emergence as a Maritime Power (Boulder: Westview, 1983), pp. 152-154; Gerald Segal, Defending China (New York and London: Oxford University Press, 1985), pp. 197-210; Chi-Kin Lo, China's Policy towards Territorial Disputes: The Case of the South China Sea Islands (New York and London: Routledge, 1989), pp. 53-60; Greg Austin, China's Ocean Frontier: International Law, Military Force and National Development (St. Leonards, Australia: Allen \& Unwin, 1998), pp. 73-77.

${ }^{18}$ LOS Convention, supra note 1, Articles 55-85.

19 Ibid., Articles 76-77.

${ }^{20}$ Timo Kivimäki, ed., War or Peace in the South China Sea (Copenhagen: NIAS Press, 2002), pp. 14-15.

21 Samuels, supra note 17, 104.

22 Statement of the Spokesman of the Foreign Ministry of the People's Republic of China, 4 February 1974, People's Daily, 5 February 1974, 1 and People's Daily, 21 January 1974, 1.

23 Vietnam, "White Paper on the Hoang Sa (Paracel) and Truong Sa (Spratly) Islands" (Republic of Vietnam, Ministry of Foreign Affairs: 1979), available at <paracelspratlyislands.blogspot.com/2008/01/white-papers-of-republic-of-vietnam.html>.

${ }^{24}$ Vũ Quang Việt, "Towards a just and fair resolution to the conflicts in the Southeast Asian Sea” (working paper, unpublished, 18 August 2010, available in files of the authors), Annex (Table of chronicle of events relating to the Paracels and Spratly Islands), note 184.

25 Ibid., note 185 .

${ }^{26}$ Declaring Certain Area Part of the Philippine Territory and Providing for Their Government and Administration, Presidential Decree No. 1596, 11 June 1978, available at <www.lawphil.net/statutes/presdecs/pd1978/pd_1596_1978.html>.

27 Philippines, Establishing An Exclusive Economic Zone and For Other Purposes, Presidential Decree No. 1599, 11 June 1978, available at <www.lawphil.net/statutes/presdecs/pd1978/pd_1599_1978.html>.

${ }^{28}$ Statement on the Territorial Sea, the Contiguous zone, the Exclusive Economic Zone, and the Continental Shelf of Vietnam, Foreign Broadcast Information Service (FBIS), Daily Report: Asia \& Pacific, 24 May 1977. See: Epsey 
Cooke Farrell, The Socialist Republic of Vietnam and the Law of the Sea: An Analysis of Vietnamese Behavior within the Emerging International Oceans Regime (The Hague: Martinus Nijhoff, 1998), pp. 46 and 101.

${ }^{29}$ People's Daily, 27 April 1979, 5.

${ }^{30}$ Chi-Kin Lo, supra note 17, 126-128.

${ }^{31}$ People's Daily, 27 September 1979, 5.

32 People's Daily, 31 January 1980, 1.

33 Vietnam, "The Hoang Sa and Truong Sa Archipelagoes: Vietnamese Territories", (Ministry of Foreign Affairs, Socialist Republic of Vietnam, 1981), available at < hoangsa.org/tailieu/Bo_ngoai_giaoVietnam81.pdf $>$.

${ }^{34}$ Kuo-Tsai Chao, supra note 3, 341-342.

${ }^{35}$ B.A. Hamzah, "Malaysia and the Law of the Sea: Post-UNCLOS III Issues," in Park and Park, supra note 3, 356.

${ }^{36}$ Cambodia, Statement Issued by the Spokesman of the Ministry of Foreign Affairs of 15 January 1978, available on the website of the U.N. Division of Ocean Affairs and the Law of the Sea (DOALOS) at $<$ www.un.org/Depts/los $>$.

${ }^{37}$ Declaration by the Government of Indonesia concerning the Exclusive Economic Zone of Indonesia, 21 March 1980 and Singapore Government Press Release, "Exclusive Economic Zone”, (Ministry of Foreign Affairs, 15 September 1980), available on the DOALOS website, supra note 36.

${ }^{38}$ Royal Proclamation establishing the Continental Shelf of the Kingdom of Thailand in the Gulf of Thailand, 18 May 1973, and Royal Proclamation establishing the Exclusive Economic Zone of the Kingdom of Thailand, 23 February 1981, available on the DOALOS website, supra note 36.

${ }^{39}$ See the listings for individual States on the DOALOS website, supra note 36.

40 Tønnesson, supra note 13, 3-14, 48-56.

${ }^{41}$ Continental Shelf Convention, supra note 15.

42 Zhong-yang-zhi-bao (Central Daily News), Taipei, Taiwan, 26 February 1987, 1.

${ }^{43}$ Michael Bennett, "The People's Republic of China and the Use of International Law in the Spratly Islands," 28 Stanford Journal of International Law (1992), p. 428.

${ }^{44}$ See Peter Kien-hong Yu, International Governance and Regimes: A Chinese Perspective (New York: Routledge, 2012), p. 83 and Wen Wei Po (Hong Kong), 10 April 1988, cited in Lee Lai To, China and the South China Sea Dialogue (Praeger Publishers, 1999), p. 14. 
${ }^{45}$ Yongshu Jiao (Fiery Cross Reef), Chigua Jiao (Johnson South Reef), Dongmen Jiao, Nanxun Jiao (Gaven Reef), Zhubi Jiao (Subi Reef), and Huahang Jiao (Guarteron Reef). See Pan Shiying, "The Nansha Islands: A Chinese point of view," Window (Hong Kong), 3 Sept. 1993, p. 29. and Lu Ning, supra note 17, 87-93. See also Min Gyo Koo, Island Disputes and Maritime Regime Building in East Asia: Between a Rock and a Hard Place (London and New York: Springer, 2009), p. 154.

${ }^{46}$ If features are above water at low tide, they are called "low tide elevations": LOS Convention, supra note 1, article 13; Yoshifumi Tanaka, The International Law of the Sea (Cambridge: Cambridge University Press, 2012), pp. 69-72; R.R. Churchill and A. V. Lowe, The law of the sea (Manchester: Manchester University Press, 1999, $3^{\text {rd }}$ ed.), pp. 48-50. While the LOS Convention does not allow constantly submerged reefs to generate any maritime zones, low tide elevations situated within the $12 \mathrm{~nm}$ territorial sea of an island or mainland coast may be used as basepoints for measuring maritime zones. In those cases they must therefore be considered part of a sovereign territory. However, in those cases when they cannot be used as basepoints they must be seen as part of the seafloor. It then follows that their natural resources belong to the continental shelf of the nearest land territory if the distance is less than $200 \mathrm{~nm}$. If further away, they may be part of an extended continental shelf or fall within what the LOS Convention refers to as the Area. Churchill and Lowe point out that the effect of articles 13 and 121.3 is "the rather anomalous result that a low-tide elevation can sometimes [because of article 13] generate an exclusive economic zone, whereas an uninhabitable 'rock' cannot [because of article 121.3], even though the latter will usually be a much more visible manifestation of land." (p. 50).

47 The Washington Post, 6 April 1988, 32.

48 "Conflict in Spratlys Spur Rift between Hanoi and Moscow," The Christian Science Monitor, 14 June 1988, 8.

${ }^{49}$ Shi-je-zhi-bao (World Journal), 16 March 1989, 31.

50 World Journal, 7 August 1989 and Central Daily News, 8 August 1989, 1.

${ }^{51}$ Central Daily News, 10 October 1989, 4.

52 John W. Garver, "China's Push Through the South China Sea: The Interaction of Bureaucratic and National Interests," The China Quarterly 132 (December 1992), 1015.

53 "Reef Knots: China Seeks Asean Support for Spratly Plan," Far Eastern Economic Review 30 August 1990, 11.

${ }^{54}$ See: Proceedings of the Workshop on Managing Potential Conflicts in the South China Sea, Bandung, 15-18 July 1991, Annex O: Speech on Political and Security Issues by Professor Wang Ying-fan, pp. 191-194. 
${ }^{55}$ China, Law on the Territorial Sea and Contiguous Zone, 25 February 1992, on the DOALOS website, supra note 36. See also: Bureau of Oceans and International Environmental and Scientific Affairs (BOIESA), United States Department of State, Limits in the Seas: Straight Baselines Claim: China, 117, 9 July 1996, pp. 11-14.

${ }^{56}$ Barry Wain, "Beijing and Hanoi Play with Fire in South China Sea," The Asian Wall Street Journal, 20 July 1994, 5.

57 “China Stirs the Pot,” Far Eastern Economic Review, 9 July 1992, 14.

58 Wain, supra note 56.

59 Lein-he-bao (United Daily News), Taipei, Taiwan, 1 December 1992, 10.

${ }^{60}$ The 1992 Declaration is available at $<$ www.aseansec.org/1196.htm $>$.

${ }^{61}$ Treaty of Amity and Cooperation in Southeast Asia, 24 February 1976, available at <www.asean.org/1217.htm>.

${ }^{62}$ United Daily News, Taipei, Taiwan, 22 July 1994, 1.

63 The declarations to the LOS Convention are available at

$<$ www.un.org/Depts/los/convention_agreements/convention_declarations.htm>.

${ }^{64}$ LOS Convention, supra note 1, preamble.

65 “Spratlys Tension Helps Push Forces Upgrade,” Jane’s Defense Weekly, 25 February 1995, 6.

${ }^{66}$ Statement by the ASEAN Foreign Ministers on the Recent Developments in the South China Sea, 18 March 1995, available at $<$ www.aseansec.org/2089.htm>.

${ }^{67}$ Statement by Christine Shelly, acting Spokesman, 10 May 1995, in U.S. Interest in Southeast Asia, Hearing before the Subcommittees on International Economic Policy and Trade and Asia and the Pacific of the Committee on International Relations, House of Representatives, $104^{\text {th }}$ Congress, $2^{\text {nd }}$ Session, 30 May and 19 June 1996 (Washington, D.C.: GPO, 1997), 157.

68 "Dialogue between Vice Premier and Foreign Minister Qian Qichen and ASEAN," Press Release, 31 July 1995 (in Chinese).

${ }^{69}$ Joint Statement, Republic of the Philippines and the People's Republic of China on the South China Sea and on Other Areas of Cooperation, Manila, 9-10 August 1995, available in Yann-huei Song, "United States and Territorial Disputes in the South China Sea: A Study of Ocean Law and Politics," Maryland Series in Contemporary Asian Studies, Vol. 2002, No. 1, Appendix B, 297-98. 
70 Joint Statement on the Fourth Annual Bilateral Consultations between the Socialist Republic of Vietnam and the Republic of Philippines, Hanoi, 7 November 1995, available in Yann-huei Song, supra note 69, Appendix B, 299-301.

71 Bangkok Summit Declaration, 14-15 December 1995, para. 7, available at <www.aseansec.org/5189.htm $>$.

${ }^{72}$ Royal Proclamation establishing the Contiguous Zone of the Kingdom of Thailand, 14 August 1995, on the

DOALOS website, supra note 36.

73 Act No. 6 of 8 August 1996 regarding Indonesian Waters, on the DOALOS website, supra note 36.

${ }^{74}$ For China's declaration, see LOS Convention declarations website, supra note 63.

75 Declaration of the Government of the People's Republic of China on the Baselines of the Territorial Sea, 15 May 1996, Law of the Sea Bulletin, No. 32, 1996, 37-40 and on the DOALOS website, supra note 36.

76 Statement of the Department of Foreign Affairs of the Philippines on the Ratification by China of the United Nations Convention on the Law of the Sea, Law of the Sea Bulletin, No. 32, 1996, 88.

77 Vietnam's Objections to the Statement of 15 May 1996 made by the Government of the People’s Republic of China on the baselines from which the breadth of Chin's territorial sea is measured, Law of the Sea Bulletin, No. 32 , $1996,91$.

78 “Beijing Questioned Over Sea Claims," South China Morning Post, 22 July 1996, 11.

79 “ASEAN Demands China Explain Baselines in S. China Sea,” Asian Political News, 29 July 1996.

${ }^{80}$ Limits in the Seas, No. 117, supra note 55, 11-14.

81 Ibid., 8.

82 “U.S. Warns China on Sea Expansion,” International Herald Tribune, 19 September 1996.

83 “China Warns Philippines over Flag on Shoal," Reuters North American Wire, 13 May 1997.

${ }^{84}$ China, Law on the Exclusive Economic Zone and the Continental Shelf, 26 June 1998, on the DOALOS website, supra note 36 .

${ }^{85}$ It has been suggested that this wording constituted a claim by China to historic rights for the waters within the U-shaped line. Authors' correspondence with Chinese scholar who is now a research fellow overseas. 
86 "US solon to Washington: Stop Chinese in Spratlys," The Philippine Star, 14 Dec 1998, available at

$<$ http://www.oocities.org/researchtriangle/thinktank/3964/china.html>

87 Bill Gertz, “China Makes Upgrade to Islands Base, Coastline,” The Washington Times, 11 February 1999.

88 “Manila: Chinese Helipad, Radars Seen in Spratlys,” Reuters, 16 February 1999.

89،Vietnam, Taiwan Fortifying Structures in the Spratlys," Kyodo World News Service, 21 September 1999.

90 "Philippines Protests attack by Vietnamese in Spratlys," Taiwan News, 29 October 1999, 5.

91 For discussion of the incident, see: Margaret K. Lewis, "Note: An Analysis of State Responsibility for the Chinese-American Airplane Collision Incident," 77 New York University Law Review (2002), 1404.

92 Declaration on the Conduct of the Parties, supra note 10.

93 Ibid., para. 5.

94 See: Erik Franckx, “American and Chinese Views on Navigational Rights of Warships," 10 Chinese Journal of International Law (2011), 187-206 and Peter Dutton, ed. Military Activities in the EEZ. A U.S.-China Dialogue on Security and International Law in the Maritime Commons (Newport, Rhode Island: Naval War College, China Maritime Studies Institute, No. 7, 2010).

95 Agreement between China and Viet Nam on the Delimitation of the Territorial Seas, the Exclusive Economic Zones and Continental Shelves in Beibu Bay/Bac Bo Gulf, 25 December 2000, Law of the Sea Bulletin, No. 56, 2004, 137. See: Zou Keyuan, "The Sino-Vietnamese Agreement on Maritime Boundary Delimitation in the Gulf of Tonkin," 36 Ocean Development and International Law (2005), 13-24; Nguyen Hong Thao, "Maritime Delimitation and Fisheries Cooperation in the Tonkin Gulf," 36 Ocean Development and International Law (2005), 25-44; and Ramses Amer and Nguyen Hong Thao, “The Management of Vietnam’s Border Disputes: What Impact on Its Sovereignty and Regional Integration? 27 Contemporary Southeast Asia, (2005), 429-452.

96 The Joint Declaration is available at < aseansec.org/15265.htm $>$. 
97 Instrument of Accession to the Treaty of Amity and Cooperation in Southeast Asia, done at Bali, Indonesia on 8 October 2003, and signed by Li Zhaoxing, Minister of Foreign Affairs, the People's Republic of China, available at $<$ www.aseansec.org/15271.htm>.

98 The Plan of Action is available at <www.aseansec.org/16805.htm $>$.

99 For details of the agreement, see

<www.scribd.com/doc/98998567/Tripartite-Agreement-Marine-Scientific-Research> and

<nghiencuubiendong.vn/en/datbase-on-south-china-sea-study/doc_details/48-a-tripartite-agreement-for-joint-marine -scientific-research-in-certain-areas-in-the-south-china-sea>. See also: Aileen S.P. Baviera, "The Influence of Domestic Politics on Philippine Foreign Policy: The case of Philippines-China relations since 2004,” RSIS Working Paper No. 241, 5 June 2012, available at <www.rsis.edu.sg/publications/WorkingPapers/WP241.pdf>.

100 “Commentary: Turning 'sea of disputes' into ‘sea of cooperation,” Peoples Daily, 16 March 2005, available at <english.peopledaily.com.cn/200503/16/eng20050316_177021.html>.

101 See: Yann-huei Song, "The Declaration on the Conduct of Parties and a Code of Conduct in the South China Sea: Recent Actions Taken by ASEAN," Asia-Pacific Forum, No. 52, June 2011, Center for Asia-Pacific Area Studies, RCHSS, Academia Sinica, Taipei, Taiwan, pp. 1-54 and Carlyle A. Thayer, "Will the Guidelines to Implement the DOC Lessen Tensions in the South China Sea? An Assessment of Developments Before and After Their Adoption,” paper presented at the $3^{\text {rd }}$ International Workshop on the South China Sea co-sponsored by the Vietnam Lawyers' Association and the Diplomatic Academy of Vietnam, Hanoi, Vietnam, 3-5 November 2011.

102 The government of the Republic of China (Taiwan) reiterates its sovereignty over the Spratly Islands and has proposed a Spratly Initiative that focuses on environmental protection instead of sovereignty disputes, Ministry of Foreign Affairs, Republic of China, 15 August 2008, available at $<$ http://www.mofa.gov.tw/EnPDA/News/Detail/4bf0f522-2c04-472b-b27d-b059f346fd5c?arfid=7b3b4d7a-8ee7-43a 9-97f8-7f3d313ad781>.

${ }^{103}$ See: Jonathan G. Odom, “The True 'Lies' of the Impeccable Incident: What Really Happened, Who Disregarded International Law, and Why Every Nations (Outside of China) Should Be Concerned," 18 Michigan State Journal of International Law 411 (2010); Mark J. Valencia, “The Impeccable Incident: Truth and Consequences,” 5 China Security 22 (Spring 2009); and, more generally see: Dutton, supra note 94. 
104 Ann Scott Tyson, "U.S. Protests Chinese Shadowing in International Waters," The Washington Post, 10 March 2009, available at <www.washingtonpost.com/wp-dyn/content/article/2009/03/09/AR2009030900956.html?hpid=moreheadlines $>$ and David Morgan, “U.S. says Chinese vessels harassed Navy ship,” Reuters, 9 March 2009, available at <www.reuters.com/article/2009/03/09/us-usa-china-navy-idUSTRE52845A20090309>.

105 “China hits out at US on navy row," BBC News, 10 March 2009, available at <news.bbc.co.uk/2/hi/asia-pacific/7934138.stm>.

106 “China says U.S. naval ship breaks int'1, Chinese law,” China News, 10 March 2009, available at <news.xinhuanet.com/english/2009-03/10/content_10983647.htm>.

107 See generally: Dutton, supra note 94.

108 See LOS Convention, supra note 1, Article 76 and Annex II regarding the Commission. The 2009 timing was a product of decisions made by the Meeting of the State Parties to the LOS Convention (SPLOS). Respecting the Commission generally, see the website of the Commission at $<$ www.un.org/Depts/los/clcs_new/clcs_home.htm $>$.

109 The Joint Submission of Malaysia and Vietnam is available on the Commission website, supra note 108.

110 The Submission of Vietnam regarding the Northern Area of the South China Sea is available on the Commission website, supra note 108 .

111 See: Communication to the Secretary-General of the United Nations, dated 7 May 2009 from China; 8 May 2009 from Vietnam; 4 August 2009 from the Philippines; 18 August 2009 from Vietnam; 21 August 2009 from Malaysia; 8 July 2010 from Indonesia; 5 April 2011 from the Philippines; 14 April 2011 from China; and 3 May 2011 from Vietnam. All of these communications are available on the Commission website, supra note 108. For Taiwan's statements of 5, 8, and 12 May 2009, see: <www.mofa.gov.tw/webapp/ct.asp?xItem=40533\&ctNode=2039\&mp=1 $>$ (in Chinese).

112 China, notes verbale, 7 May 2009, supra note 111, para. 2

113 See Masahiro Miyoshi, “China’s 'U-Shaped Line' Claim in the South China Sea: Any Validity Under International Law," Ocean Development and International Law, Vol. 43, No. 1, 2012, 1-17; Michael Sheng-Ti Gau, "The U-Shaped Line and a Categorization of the Ocean Disputes in the South China Sea," Ocean Development and 
International Law, Vol. 43, No. 1, 2012, 57-69; Nguyen Dang Thang and Nguyen Hong Thao, “China’s Nine Dotted Lines in the South China Sea: the Exchange of Diplomatic Notes Between the Philippines and China," Ocean Development and International Law, Vol. 43, No. 1, 2012, 35-56; Zou Keyuan, “China's U-Shaped Line in the South China Sea Revisited," Ocean Developmetn and International Law, Vol. 43, No. 1, 2012, 18-34; Li Jinming and Li Dexia (2003), “The Dotted Line on the Chinese Map of the South China Sea: A Note,” Ocean Development and International Law, Vol. 34, 2003, 287-296; Peter Dutton, “Three Disputes and Three Objectives: China and the South China Sea,” Naval War College Review, Vol, 64, No. 4, Autumn 2011, 42-67; Tran Truong Thuy, “China’s U-shaped Line in the South China Sea: Possible Interpretations, Asserting Activities and Reactions from Outside," paper presented at the Conference on "The Practices of the UNCLOS and the Resolution of South China Sea Disputes", 3-4 September 2012, Taipei; Hong Nong, "Interpreting the U-shaped Line in the South China Sea," China \& US Focus, 15 May 2012, available at

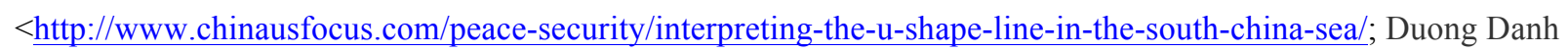
Huy, "China's "U-shaped Line" in the South China Sea," Yale Global Online, 24 September 2012, available at $<\underline{\text { http://yaleglobal.yale.edu/content/chinas-u-shaped-line-south-china-sea }>}$.

114 China, note verbale, 7 May 2009, supra note 111, para. 2.

115 Vietnam, note verbale, 8 May 2009, supra note 111.

116 Malaysia, note verbale, 20 May 2009, supra note 111.

117 Indonesia, note verbale, 8 July 2010, supra note 111.

118 The Philippines, note verbale 4 August 2009, supra note 111.

119 The Philippines, note verbale, 5 April 2011, supra note 111. 
120 China, note verbale, 3 May 2011, supra note 111.

121 “China's largest fishery patrol ship starts mission,” Xinhua News, 11 March 2009, available at <news.xinhuanet.com/english/2009-03/11/content_10993996.htm>; "One more ship to patrol South China Sea," People's Daily Online, 15 May 2009, available at <english.peopledaily.com.cn/90001/90776/90882/6658790.html>; and "Reinforced patrol sails from Hainan," China Daily, 19 May 2009, available at <www.chinadaily.com.cn/china/2009-05/19/content_7790652.htm>.

122 "Fishing ban starts in the South China Sea," Xinhua News, 17 May 2012, available at <news.xinhuanet.com/english/china/2012-05/17/c_131592412.htm>.

123 See, for example, “China again demands money for Vietnamese fishermen,” Viet Channel, 7 July 2009 , available at < vietchannel.wordpress.com/2009/07/07/china-again-demands-money-for-vietnamese-fishermen/>; "Vietnam asks China to return seized fishing boats," Vietnews, 30 March 2010, available at <www.vietnewsonline.vn/News/Politics/13803/Vietnam-asks-China-to-return-seized-fishing-boat.htm>; and “China navy boards Vietnam boat in sea spat," Agence France-Presse, 15 July 2011, available at <www.abs-cbnnews.com/global-filipino/world/07/14/11/china-navy-boards-vietnam-boat-sea-spat>.

124 "China fired at Filipino fishermen in Jackson atoll," $A B S-C B N$ News, 3 June 2011, available at <www.abs-cbnnews.com/-depth/06/02/11/china-fired-filipino-fishermen-jackson-atoll $>$.

${ }^{125}$ In accordance with Section 2 of the Republic Act No. 9522, the baseline in the Kalayaan Island Group over which the Philippines exercises sovereignty and jurisdiction are determined as "Regime of Islands" consistent with Article 121 of the LOS Convention. Republic Act No. 9522, 10 March 2009, An Act to Amend Certain Provisions of Republic Act No. 3046, As Amended by Republic Act No. 5446, to Define the Archipelagic Baseline of the Philippines and for Other Purposes, visit the Lawphil Project, Philippine Laws and Jurisprudence Databank, at <www.lawphil.net/statutes/repacts/ra2009/ra_9522_2009.html >.

${ }^{126}$ China, Foreign Ministry Spokesperson Jiang Yu’s Regular Press Conference, 20 October 2011, available at <www.fmpre.gov.cn/eng/xwfw/s2510/2511/t869942.htm>.

127 "Philippines rejects Chinese demand to return boats seized from disputed area," BBC Monitoring Asia Pacific Political, 23 October 2011.

128 “China ratcheting up regional tension,” Asahi Shimbun, 24 July 2010, available at <www.asahi.com/english/TKY201007230527.html>. 
129 "Why is China Picking Fights with Indonesia?” The Weekly Standard, 6 August 2010, available at <www.weeklystandard.com/blogs/why-china-picking-fights-indonesia > and "Is China a neighbor to Indonesia," The Jakarta Post, 8 August 2011, available at $<$ www.thejakartapost.com/news/2011/08/08/is-china-a-neighbor-indonesia.html>.

130 Agreement between Malaysia and Indonesia on the Delimitation of the Continental Shelf between the Two Countries, 27 October 1969, on the DOALOS website, supra note 36.

131 Agreement between Vietnam and Indonesia concerning the Delimitation of the Continental Shelf Boundary, 26 June 2003, Law of the Sea Bulletin, No. 67, 2008, 39.

${ }^{132}$ Ian Storey, "China and the Philippines: Implications of the Reed Bank Incident," China Brief, Vol. 11, Issue 8, 6 May 2011, pp. 6-8, available at <www.jamestown.org/uploads/media/cb_11_8_03.pdf $>$.

133 Carlyle A. Thayer, "Security Cooperation in the South China Sea: An Assessment of Recent Trends," paper presented at the First Manila Conference on the South China Sea: The South China Sea: Toward a Regional of Peace, Cooperation, and Progress, 5-6 July 2011, Makati City, the Philippines, pp. 16-17. See also Michaela P. del Callar and Mario J. Mallari. “RP gov’t protests China’s planned oil rig, constructions in Reeds, Spratlys,” The Daily Tribune, 2 June 2011, available at <www.tribuneonline.org/headlines/20110602hed4.html>.

134 Andrew Higgins, "In South China Sea, a dispute over energy," The Washington Post, 18 September 2011, available at

<www.washingtonpost.com/world/asia-pacific/in-south-china-sea-a-dispute-over-energy/2011/09/07/gIQA0PrQaK_ story.html>.

135 "Manila rejects new Chinese claim to territory just 50 miles away from Philippine province," The Washington

Post, 14 November 2011, available at

$<$ www.washingtonpost.com/world/asia-pacific/manila-rejects-new-chinese-claim-to-territory-just-50-miles-away-fr om-philippine-province/2011/11/14/gIQAv3lmJN_print.html>.

136 “Vietnam demands China stop sovereignty violations," Thanh Nien Daily, 29 May 2011, available at <www.thanhniennews.com/2010/Pages/20110530011353.aspx>.

137 "Vietnam alleges high-seas interference," iStockAnalyst, 10 June 2011, available at $<$ www.istockanalyst.com/business/news/5222203/vietnam-alleges-high-seas-interference $>$. 
138 “China, Vietnam sign accord on resolving maritime issues,” Xinhua, 12 October 2011, available at

<news.xinhuanet.com/english2010/china/2011-10/12/c_131185606.htm> (accessed 24 October 2011).

139 Ibid. On the talks up to 2010, see Carlyle Thayer "The Tyranny of Geography: Vietnamese Strategies to

Constrain China in the South China Sea," 33 Contemporary Southeast Asia (2011), 350.

140 See supra note 95 and accompanying text.

141 Reported in M. Taylor Fravel, “Clarifying China’s Claim,” The Diplomat 5 March 2012, available at $<$ the-diplomat.com/china-power/2012/03/05/clarification-of-china $\%$ E2\%80\%99s-claim/comment-page-1/\#comment $-7077>$.

142 Ben Bland, et. al., "US gas find off Vietnam adds to China tension," The Financial Times, 26 October 2011, available at <www.ft.com/intl/cms/s/0/e5674186-ffe5-11e0-ba79-00144feabdc0.html\#axzz1dqfBMYBw>.

143 “Vietnam introduces Maritime Law," VietnamNet, 17 July 2012, available at http://english.vietnamnet.vn/fms/government/24535/vietnamintroduces-maritime-law.html. The full Vietnamese text of the law can be found at: Carlyle A. Thayer, "Viet Nam Law of the Sea", Thayer Consultancy Background Brief, 5 August 2012. http://www.scribd.com/doc/101998223/Thayer-Vietnam-s-Law-on-the-Sea

144 “Notification of Part of Open Blocks in Waters under Jurisdiction of the People's Republic of China Available for Foreign Cooperation in the Year of 2012,” 23 June 2012, available at

<en.cnooc.com.cn/data/html/news/2012-06-23/english/322127.html>.

145 Teddy Ng, "New city to run disputed island chains," South China Morning Post, 22 June 2012.

146 “Philippines Slams China's Establishment of Sansha City in South China Sea,” VOA News, 23 July 2012, available at <www.voanews.com/content/philippines-slams-chinese-establishment-of-city-in-south-china-sea/1443944.html>. 147 Jim Gomez, "Philippine warship in standoff with China vessels," Associated Press Online, 11 April 2012. 148 See Ding Gang, "More ‘doing’ required in the South China Sea," Huanqiu Shibao (Global Times), 29 August 2012, English translation, available at <southseaconversations.wordpress.com/2012/08/30/more-doing-required-ding-gang-brings-the-taoguang-yanghui-d ebate-to-the-south-china-sea/>. 
${ }^{149}$ Secretary of State Hillary R. Clinton, "Remarks With Secretary of Defense Leon Panetta, Philippines Foreign Secretary Albert del Rosario, and Philippines Defense Secretary Voltaire Gazmin After Their Meeting,” 30 April 2012, available at <www.state.gov/secretary/rm/2012/04/188982.htm>.

150 “VN opposes Taiwanese officials’ visit to Spratly,” States News Service, 10 May 2012.

${ }^{151}$ Joint Communiqué of the 43rd ASEAN Foreign Ministers Meeting -- "Enhanced Efforts towards the ASEAN Community: from Vision to Action", Ha Noi, Vietnam, 19-20 July 2010, available at $<$ www.aseansec.org/24899.htm>.

${ }^{152}$ Secretary Clinton's remarks made on 23 July 2010, available at $<$ www.state.gov/secretary/rm/2010/07/145095.htm>.

${ }^{153}$ Nirmal Ghosh, "Asean meeting fails to reach agreement on joint statement; Lack of accord unprecedented, blow to grouping's credibility: Shanmugam,” The Straits Times (Singapore) July 14, 2012.

154 The Philippine Star, 21 July 2012:

$<$ www.philstar.com/article.aspx?articleid=829785\&publicationsubcategoryid=200>. Statement of ASEAN Foreign Ministers on ASEAN's Six-Point Principles:

$<$ www.mfaic.gov.kh/mofa/default.aspx?id=3206\&utm_source=buffer\&buffer_share=b1430 $>$. Joint statement of China and ASEAN, 19 November 2012: "Full Text of ASEAN-China Joint Statement", http://english.cri.cn/6909/2012/11/20/191s733809.htm> Chairman's Statement of the 22nd ASEAN Summit, "Our People, Our Future Together”, Bandar Seri Begawan, 24-25 April 2013: < http://www.asean.org/news/asean-statement-communiques/item/chairmans-statement-of-the-22nd-asean-summit-our -people-our-future-together>

$155<\mathrm{http}: / /$ www.un.org/Depts/los/clcs_new/submissions_files/submission_chn_63_2012.htm>

${ }^{156}$ Notification and Statement of Claim on West Philippine Sea”, The Philippines to the People's Republic of China, no. 13-0211, 22 January 2013:

$<$ http://www.dfa.gov.ph/index.php/newsroom/dfa-releases/7300-statement-by-secretary-of-foreign-affairs-albert-del -rosario-on-the-unclos-arbitral-proceedings-against-china-to-achieve-a-peaceful-and-durable-solution-to-the-dispute -in-the-wps>

${ }^{157}$ For the Chinese declaration, visit the website of the United Nations at $<$ http://www.un.org/Depts/los/convention_agreements/convention_declarations.htm> 
158 “Polish judge picked for Phl-China arbitration," The Philippine Star, 26 March 2013, available at <http://www.philstar.com/headlines/2013/03/26/924087/polish-judge-picked-phl-china-arbitration> 159 "ITLOS appoints 3 members of UN tribunal," The Philippine Star, available at <http://www.philstar.com/headlines/2013/04/26/935048/itlos-appoints-3-members-un-tribunal> 160 “UNCLOS Annex VII Arbitration - Who, What, Where, When?” Blog posted by Naomi Burke on 25 March 2013 at the Cambridge Journal of International and Comparative Law website, available at $<$ http://www.cjicl.org.uk/index.php/component/easyblog/unclos-annex-vii-arbitration--who-what-where-when?Itemi $\mathrm{d}=101>$

161 An excellent map showing the maximum extent of an EEZ claim based on the Spratlys and Paracels (falling far short of the U-shaped line) may be found in Sarah Raine and Christian Le Mière's recommendable booklet, Regional Order: The South China Sea Disputes (London: International Institute of Strategic Studies, 2013 ), p. 7. 162 "Statement by Secretary of Foreign Affairs Albert del Rosario on the UNCLOS Arbitral Proceedings against China to Achieve a Peaceful and Durable Solution to the Dispute in the WPS [West Philippines Sea]", http://www.dfa.gov.ph/index.php/newsroom/dfa-releases/7300-statement-by-secretary-of-foreign-affairs-albert-del-r osario-on-the-unclos-arbitral-proceedings-against-china-to-achieve-a-peaceful-and-durable-solution-to-the-dispute-i n-the-wps. See also Raine and Le Mière, supra note 160, p. 217-220; and Carlyle A. Thayer, "The Philippines' Claim to the UNCLOS Arbitral Tribunal: Implication for Vietnam” Presentation to International Workshop on The Sovereignty Over Paracel and Spratly Archipelagoes - Historical and Legal Aspects. Pham Van Dong University, Quang Ngai City, 27-28 April 2013. For the Permanent Court of Arbitration's explanation of the various arbitration options under the LOS Convention, see <www.pca-cpa.org/showpage.asp?pag_id=1288>

163 Carlyle A. Thayer, “ASEAN's Code of Conduct in the South China Sea” A Litmus Test for Community-Building?” The Asia Pacific Journal: Japan Focus, Vol. 10, Issue 34, No. 4, 20 August 2012, available at http://www.japanfocus.org/-Carlyle_A_-Thayer/3813 and "Deference/Defiance: Southeast Asia, China, and the South China Sea," paper presented at International Studies Association Annual Conference, San Francisco, 5 April 2013, pp. 20-26. 